Prepared in Cooperation with the Indiana Department of Natural Resources, Division of Reclamation

\title{
Occurrence and Attempted Mitigation of Carbon Dioxide in a Home Constructed on Reclaimed Coal-Mine Spoil, Pike County, Indiana
}

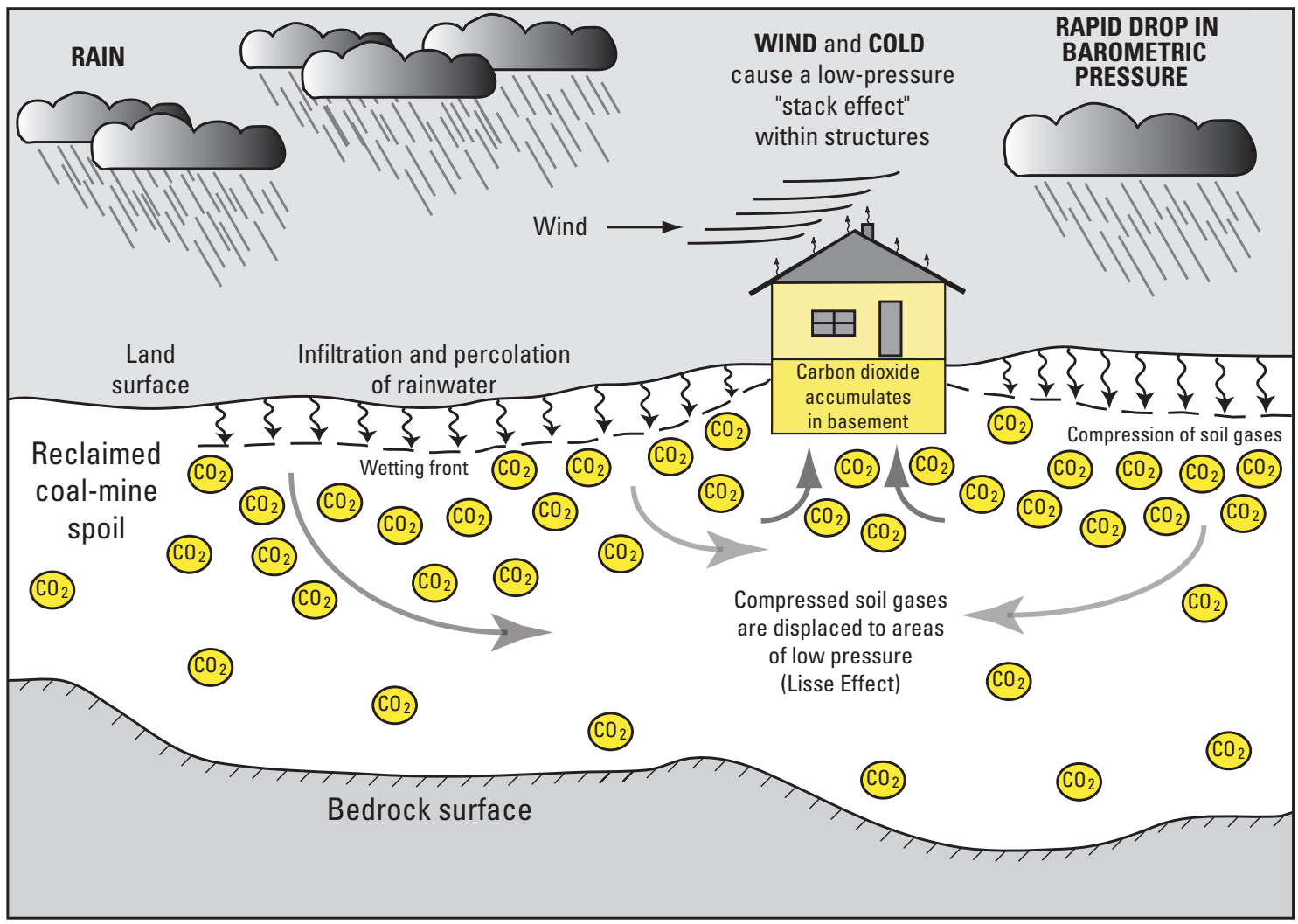

Scientific Investigations Report 2010-5157 
Cover image (also figure 7 in report): Conceptual model depicting four of the environmental conditions that may lead to carbon dioxide intrusion to structures: rapid drops in barometric pressure, rain, wind, and cold. 


\section{Occurrence and Attempted Mitigation of Carbon Dioxide in a Home Constructed on Reclaimed Coal-Mine Spoil, Pike County, Indiana}

By Bret A. Robinson

Prepared in Cooperation with the Indiana Department of Natural Resources,

Division of Reclamation

Scientific Investigations Report 2010-5157 


\title{
U.S. Department of the Interior \\ KEN SALAZAR, Secretary \\ U.S. Geological Survey \\ Marcia K. McNutt, Director
}

\section{U.S. Geological Survey, Reston, Virginia: 2010}

\author{
For more information on the USGS - the Federal source for science about the Earth, its natural and living resources, \\ natural hazards, and the environment, visit http://www.usgs.gov or call 1-888-ASK-USGS \\ For an overview of USGS information products, including maps, imagery, and publications, \\ visit http://www.usgs.gov/pubprod \\ To order this and other USGS information products, visit http://store.usgs.gov
}

Any use of trade, product, or firm names is for descriptive purposes only and does not imply endorsement by the U.S. Government.

Although this report is in the public domain, permission must be secured from the individual copyright owners to reproduce any copyrighted materials contained within this report.

Suggested citation:

Robinson, B.A., 2010, Occurrence and attempted mitigation of carbon dioxide in a home constructed on reclaimed coal-mine spoil, Pike County, Indiana: U.S. Geological Survey Scientific Investigations Report 2010-5157, 21 p. 


\section{Contents}

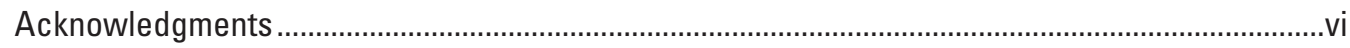

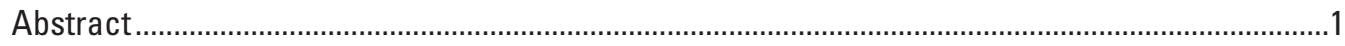

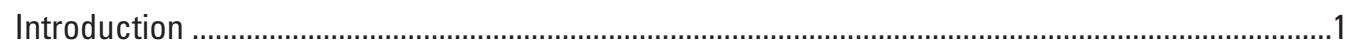

Carbon Dioxide and Associated Health Concerns ................................................................

Physical Setting and History of the Study Area.......................................................................2

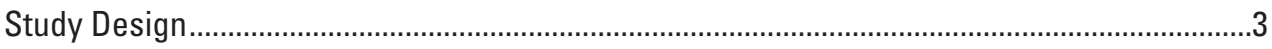

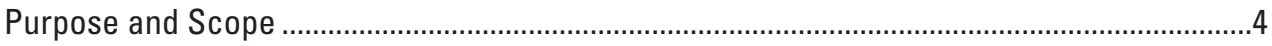

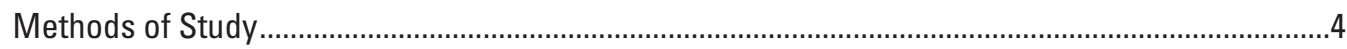

Geological Data Collection........................................................................................................... 4

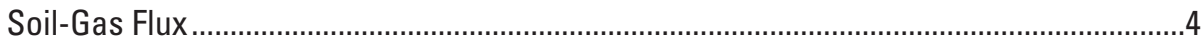

Well Construction and Groundwater-Level Measurements............................................6

Spoil Sampling and Chemical Analysis ..............................................................................

Meteorological Data Collection ............................................................................................

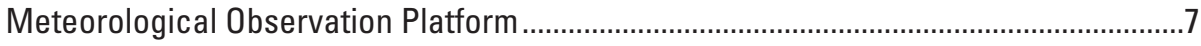

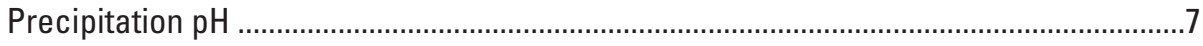

Within-Residence Data Collection .....................................................................................

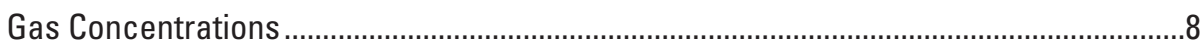

Masonry Sampling and Chemical Analysis .......................................................................8

Occurrence of Within-Residence Carbon Dioxide .............................................................................

Meteorological Controls ............................................................................................................. 10

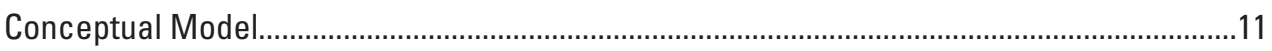

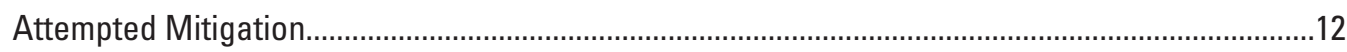

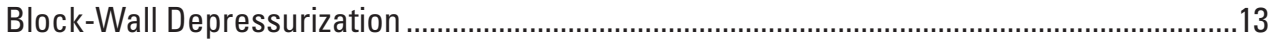

Block-Wall and Sub-Slab Depressurization .............................................................................14

Block-Wall and Sub-Slab Pressurization.................................................................................15

Limitations Regarding Extrapolation of Mitigation Results......................................................16

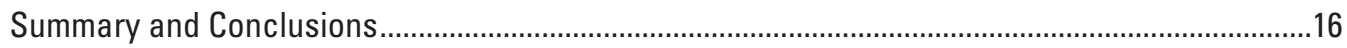

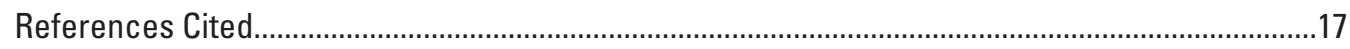

Appendix 1. Detailed Descriptive and Analytical Data From the Study Site....................................18

\section{Figures}

1. Photograph showing carbon dioxide cloud that has settled to floor level .......................2

2. Photograph showing the study-site home in east-central Pike County, Ind., where the intrusion of carbon dioxide as a soil gas has posed a health risk........................3

3. Diagram showing location of outdoor data-collection sites relative to the

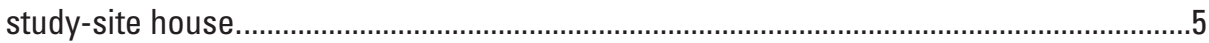

4. Photograph showing drilling activities for installation of a temporary network of monitoring wells at the study site. 
5. Photograph showing meteorological observation platform designed for hourly transmission of local meteorological data measured at the study site.

6. Graphs showing $\mathrm{CO}_{2}$-concentration, barometric-pressure, and precipitation data collected from March 25 to April 25, 2009, at the study site.

7. Conceptual model depicting four of the environmental conditions that may lead to carbon dioxide intrusion to structures: rapid drops in barometric pressure, rain, wind, and cold

8. Photograph of syringe in a beaker of water, used to illustrate the effect of how a drop in barometric pressure draws soil gases into a structure

9. Diagram showing new-construction steps that can be taken to reduce soil-gas intrusion or facilitate mitigation...

10. Photograph showing mitigation system established to depressurize the block walls of the study-site home

11-13. Graphs showing $\mathrm{CO}_{2}$-concentration, barometric-pressure, and precipitation data collected at the study site-

11. April 15 to May 10, 2009; block-wall depressurization was established on April 28, 2009

12. September 1 to October 13, 2009; a combination of block-wall and sub-slab depressurization was established on May 13, 2009

13. October 5 to November 5, 2009; a combination of block-wall and sub-slab pressurization was established on 0ctober 21, 2009

\section{Tables}

1. Selected characteristics of monitoring wells at the study site, Pike County,

Indiana .7

2. Determinations of $\mathrm{pH}$ for rainwater samples collected at the study site

1-1. Locational data for spoil samples collected at the carbon dioxide-

accumulation study site

1-2. Results of major-ion analysis of spoil samples collected at the study site

1-3. Description of materials and locations where masonry samples were collected from the study-site home

1-4. Results of major-ion analysis of masonry samples collected from the study-site home

1-5. Daily maximum carbon dioxide percentages and daily minimum oxygen percentages within the study-site home, February 18-December 30, 2009 


\section{Conversion Factors, Datums, and Abbreviated Units of Measure}

\begin{tabular}{|c|c|c|}
\hline Multiply & By & To obtain \\
\hline \multicolumn{3}{|c|}{ Length } \\
\hline inch (in.) & 2.54 & centimeter $(\mathrm{cm})$ \\
\hline foot $(\mathrm{ft})$ & 0.3048 & meter $(\mathrm{m})$ \\
\hline mile (mi) & 1.609 & kilometer (km) \\
\hline \multicolumn{3}{|c|}{ Area } \\
\hline square meter $\left(\mathrm{m}^{2}\right)$ & 10.764 & square foot $\left(\mathrm{ft}^{2}\right)$ \\
\hline acre & 0.4047 & hectare (ha) \\
\hline \multicolumn{3}{|c|}{ Volume } \\
\hline cubic feet $\left(\mathrm{ft}^{3}\right)$ & 0.0283 & cubic meter $\left(\mathrm{m}^{3}\right)$ \\
\hline \multicolumn{3}{|c|}{ Pressure } \\
\hline millibar (mbar) & 0.1 & kilopascal $(\mathrm{kPa})$ \\
\hline millibar (mbar) & 0.7501 & $\begin{array}{l}\text { millimeters of mercury } \\
\quad(\mathrm{mmHg})\end{array}$ \\
\hline
\end{tabular}

Temperature in degrees Fahrenheit $\left({ }^{\circ} \mathrm{F}\right)$ may be converted to degrees Celsius $\left({ }^{\circ} \mathrm{C}\right)$ as follows:

$$
{ }^{\circ} \mathrm{C}=\left({ }^{\circ} \mathrm{F}-32\right) / 1.8
$$

Horizontal coordinate information is referenced to the World Geodedic System of 1984 (WGS 84).

Elevation, as used in this report, refers to distance above or below a local arbitrary vertical datum established for the study site.

Gas concentrations are given in parts per million (ppm).

Carbon dioxide fluxes are given in micromoles per square meter per second $\left(\mu \mathrm{mol} / \mathrm{m}^{2} / \mathrm{s}\right)$. 


\section{Other Abbreviations}

Additional abbreviations and acronyms used in this report:

$\begin{array}{ll}\mathrm{CO}_{2} & \text { carbon dioxide } \\ \text { OSHA } & \text { Occupational Safety and Health Administration } \\ \text { ASHRAE } & \text { American Society of Heating, Refrigerating, and Air-conditioning Engineers } \\ 0_{2} & \text { oxygen } \\ \text { IDNR } & \text { Indiana Department of Natural Resources } \\ \text { USGS } & \text { U.S. Geological Survey } \\ \text { PVC } & \text { polyvinylchloride } \\ \text { NADP } & \text { National Atmospheric Deposition Program }\end{array}$

\section{Acknowledgments}

The author gratefully acknowledges those individuals who contributed to this investigation and regrets that many will remain unnamed. Steve Herbert, Jim Metzger, Randy Hoffman, Laura Montgrain, and Marvin Ellis (all of Indiana Department of Natural Resources, Division of Reclamation) provided valuable assistance with data acquisition and are acknowledged for their constructive study input. Bill Ehler (U.S. Office of Surface Mining) and the professionals at Radon Environmental Inc. provided vital technical support regarding mitigation methods. Finally, I would like to express my sincere appreciation to the Hudson family, who graciously permitted numerous intrusions of personnel and equipment to their home. By allowing us to collect the required data, they have potentially spared countless other families from having to endure the inconvenience and health risks that are associated with the $\mathrm{CO}_{2}$-intrusion phenomenon. 


\title{
Occurrence and Attempted Mitigation of Carbon Dioxide in a Home Constructed on Reclaimed Coal-Mine Spoil, Pike County, Indiana
}

\author{
By Bret A. Robinson
}

\section{Abstract}

In recent years carbon dioxide $\left(\mathrm{CO}_{2}\right)$ intrusion has become recognized as a potentially serious health threat where homes are constructed on or near reclaimed surface coal mines. When $\mathrm{CO}_{2}$ invades the living space of a home, it can collect near the floor, displace the oxygen there, and produce an oxygen-deficient environment. In this investigation, several lines of inquiry were pursued to determine the environmental factors that most influence $\mathrm{CO}_{2}$-intrusion at a Pike County, Ind., home where this phenomenon is known to occur. It was found that $\mathrm{CO}_{2}$-intrusion events at the home are most closely tied to rapid drops in barometric pressure and rainfall. Other researchers have shown that windy conditions and periods of cold weather also can contribute to soil-gas intrusion to structures. From this, a conceptual model was developed to illustrate the influence of these four meteorological conditions. Additionally, three mitigation methods - block-wall depressurization, block-wall and sub-slab depressurization, and blockwall and sub-slab pressurization-were applied successively to the study-site home, and environmental data were collected to evaluate the effectiveness of each mitigation method. In each case, it was found that these methods did not ensure a safe environment when meteorological conditions were favorable for $\mathrm{CO}_{2}$ intrusion.

\section{Introduction}

Recently it has been recognized that potentially hazardous concentrations of carbon dioxide $\left(\mathrm{CO}_{2}\right)$ may be found in structures constructed on or near surface coal mines. Several documented cases in West Virginia (Rao and Kreiss, 2004), Pennsylvania (Ehler, 2002; Laughrey and others, 2002), and Great Britain (Hendrick and Sizer, 1992) show that $\mathrm{CO}_{2}$ may be associated with either underground or surface mines and illustrate how hazardous these occurrences can be. In addition, these case studies provide some guidelines for study and mitigation in cases where elevated $\mathrm{CO}_{2}$ concentrations are suspected or realized.

Carbon dioxide, as a soil gas, may be generated by the dissolution of carbonate material within bedrock, glacial till, or coal-mine spoil; by the microbial breakdown of buried organic material; or as the direct product of biological respiration. In most documented cases of $\mathrm{CO}_{2}$ derived from reclaimed coal-mine spoil, the underlying factors that allow for the potentially hazardous generation and accumulation of $\mathrm{CO}_{2}$ are thought to include (1) a carbonate or organic source of carbon in the spoil or capping materials, (2) water chemistry appropriate to generate $\mathrm{CO}_{2}$ from the carbon-rich source material, (3) a pressure gradient that promotes $\mathrm{CO}_{2}$ migration toward the structure, (4) pathways that allow $\mathrm{CO}_{2}$ to migrate from the source area and into a structure, and (5) a structure featurebasement, crawl space, sump, or other enclosed space - that accommodates $\mathrm{CO}_{2}$ accumulation.

\section{Carbon Dioxide and Associated Health Concerns}

At standard atmospheric temperature and pressure, $\mathrm{CO}_{2}$ is a nonflammable, odorless, and colorless gas. It has a specific gravity of 1.524 , which means that in a closed container or space, without air currents to ensure mixing, $\mathrm{CO}_{2}$ will settle toward the floor (fig. 1). Although it is only slightly toxic, the primary health hazard associated with high concentrations of $\mathrm{CO}_{2}$ stems from the fact that it is an asphyxiant (that is, it displaces oxygen).

Typically the concentration of $\mathrm{CO}_{2}$ in the atmosphere ranges from 350 to 600 parts per million (ppm), with an average of approximately $380 \mathrm{ppm}$. The Occupational Safety and Health Administration (OSHA; 2009) established the workplace limit for $\mathrm{CO}_{2}$ in air at 5,000 ppm. Even lower concentrations are generally desirable for areas frequented by children, seniors, or people with special health concerns. 


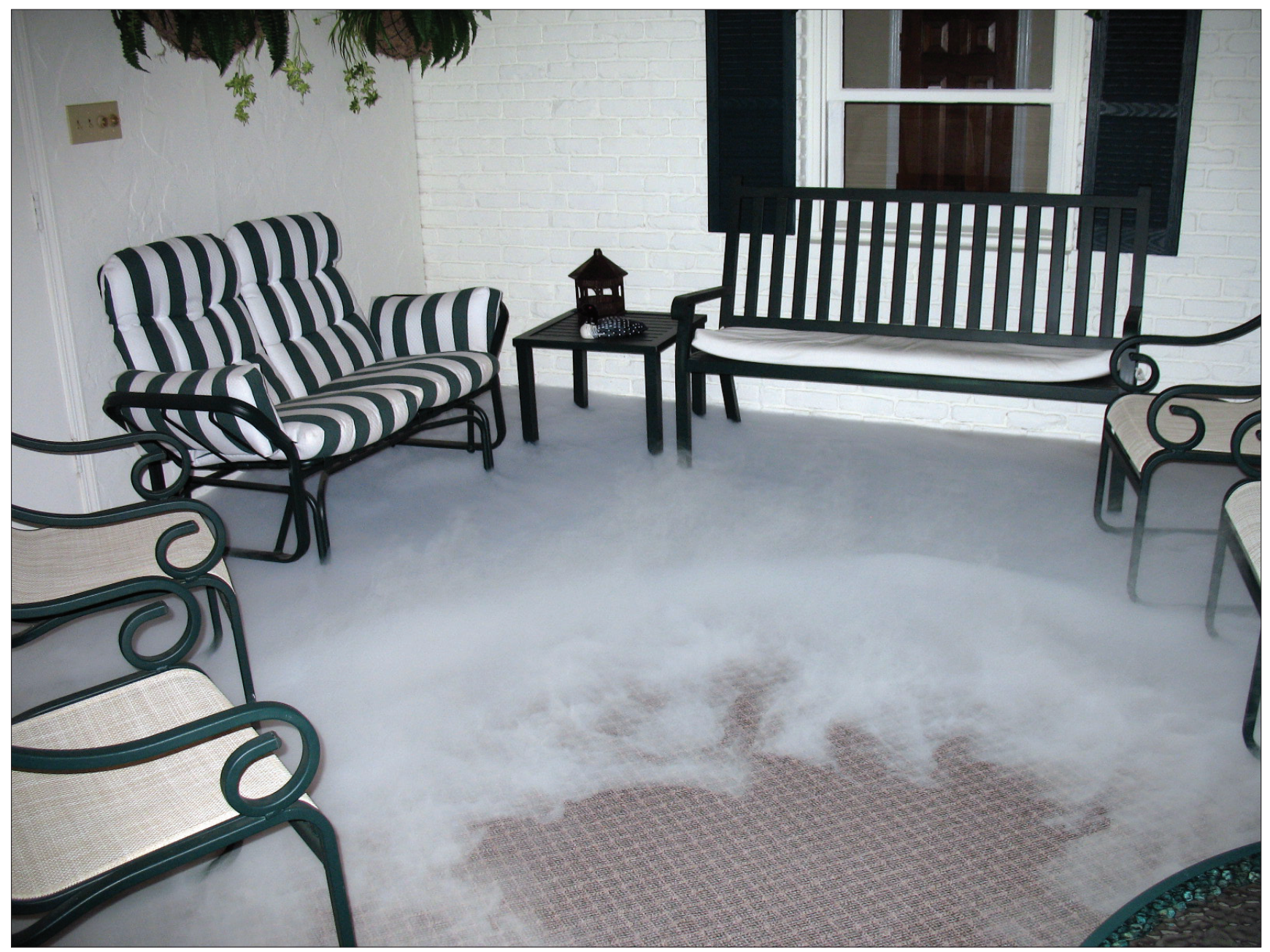

Figure 1. A carbon dioxide cloud that has settled to floor level. (In this photograph, condensation allows the dry-ice-generated carbon dioxide cloud to be visible; however, in most settings, carbon dioxide generated from natural soil processes will not be visible.)

The concentration of oxygen $\left(\mathrm{O}_{2}\right)$ in air is typically around 21 percent $(210,000 \mathrm{ppm})$; however, in areas with elevated $\mathrm{CO}_{2}$ concentrations, $\mathrm{O}_{2}$ concentrations may be reduced to dangerously low levels. OSHA Standard 29 CFR 1910.134 states that air with an $\mathrm{O}_{2}$ concentration below 19.5 percent is considered oxygen deficient. In an oxygen-deficient environment, an individual may experience a variety of symptoms: with an $\mathrm{O}_{2}$ concentration of 16 to 19 percent, breathing becomes rapid or labored; below 16 percent, individuals may experience headaches and dizziness; below 14 percent, thinking and judgment can be impaired; below 10 percent, unconsciousness and death may result (National Institute for Occupational Safety and Health, 2004). Because $\mathrm{CO}_{2}$ tends to first accumulate at floor level and displace the oxygen there, special consideration must be given for the impact that the $\mathrm{CO}_{2}$-intrusion phenomenon may have on infants, toddlers, and pets who breathe at near-floor levels.

\section{Physical Setting and History of the Study Area}

In 2006, the Indiana Department of Natural Resources (IDNR), Division of Reclamation became aware of at least three homes in southern Indiana that were experiencing elevated levels of $\mathrm{CO}_{2}$ and depressed levels of $\mathrm{O}_{2}$. All three homes were constructed on or near recently reclaimed surface coal mines. At two of the homes, mitigation efforts were able to reduce $\mathrm{CO}_{2}$ concentrations to acceptable levels. Unfortunately, at one site (fig. 2) in east-central Pike County, Ind., herein referred to as the "study site," building-foundation characteristics did not appear to be compatible with commonly applied mitigation approaches: sub-slab depressurization systems. Therefore, this site continued to represent a health hazard for the homeowners; in fact, when environmental conditions were unfavorable, the home was from time to time uninhabitable. 


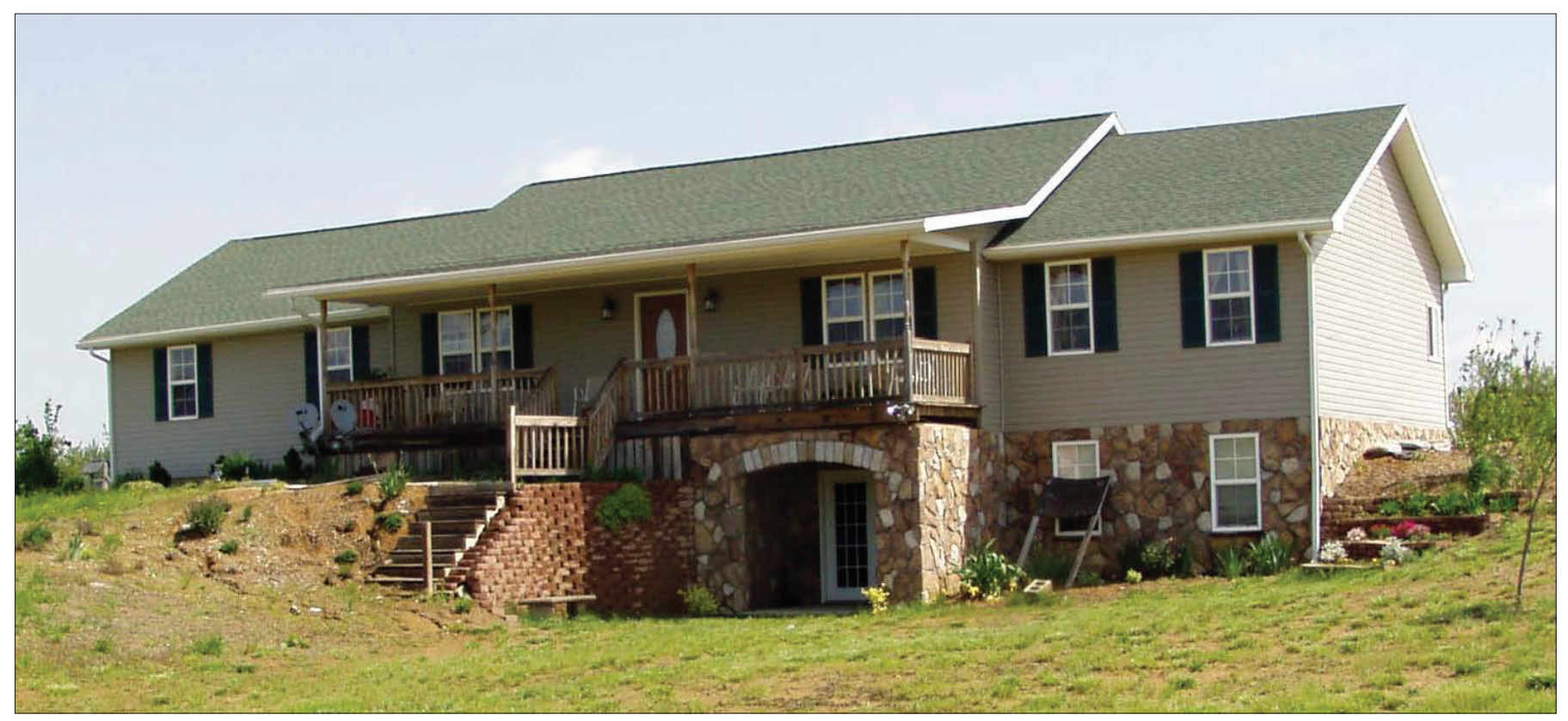

Figure 2. The study-site home in east-central Pike County, Ind., where the intrusion of carbon dioxide as a soil gas has posed a health risk.

Pike County is in southwestern Indiana. The geologic materials underlying the county are part of the Illinois Basin, a broad depression of Cambrian through Permian sedimentary rocks. In many southwestern Indiana and southern Illinois locations, surface-mining techniques are used to extract coal deposits associated with the Illinois Basin.

Mean monthly temperatures at Spurgeon, Ind., about $8 \mathrm{mi}$ southwest of the study site, range from about $30^{\circ} \mathrm{F}$ in January to about $78^{\circ} \mathrm{F}$ in July. At Spurgeon, normal annual precipitation is 46.6 in.; normal monthly precipitation ranges from about 2.6 in. in February to about 5.2 in. in May (Midwest Regional Climate Center, 2009).

The relevant history of the study site begins with the establishment of a coal mine in 1986. At this mine, the Houchin Creek Coal Member of Petersburg Formation and the Survant Coal Member of Linton Formation were extracted by means of standard surface-mining practices. Mining activity at the study site ended in 1992, and the land was then reclaimed following modern reclamation practices (Indiana Geological Survey, Coal Mine Information System, 2009). Reclamation involved returning the stripped overburden - spoil - to the mined area, capping the spoil with approximately 36 in. of soil, and establishing vegetation on the soil surface. After reclamation, the land was sold for residential development. Currently, land use in the broader study area includes widely spaced single-family units (less than one per 5 acres overall) constructed within an area of agricultural land, rangeland, and forest land (Homer and others, 2004).

The study-site home was constructed with a walk-out basement and is positioned where a level landscape surface meets a hillside that gently slopes down to a 7 -acre lake. The lake is approximately $300 \mathrm{ft}$ from the home, and the elevation of the lake's surface is approximately $20 \mathrm{ft}$ lower than the home's basement floor. The occurrence of extensive and long-lasting puddles after even moderate rain showers (less than $1 / 4 \mathrm{in}$.), indicates that the level surfaces of the study-site landscape are poorly drained.

\section{Study Design}

One aspect of the mission of the U.S. Geological Survey (USGS) is to provide reliable scientific information that describes natural systems and helps to minimize the loss of life and property that may be impacted by natural hazards. In most cases, this involves documenting and analyzing widely recognized natural hazards such as floods, earthquakes, and volcanic activity. However, on occasion previously unrecognized phenomenon, such as $\mathrm{CO}_{2}$ intusion, emerge as a newly identified natural hazard. Following the guidelines within our strategic science direction, the USGS works with its cooperative partners to document these emerging hazards and ensure that scientific methods are effectively applied to better understand the phenomenon and minimize loss.

To aid in understanding the processes that control the potential for $\mathrm{CO}_{2}$ to invade and accumulate in homes built on or near reclaimed coal mines, the USGS and the IDNR Division of Reclamation entered into a cooperative investigation of this phenomenon and of steps that might be taken to provide effective mitigation. This investigation included three primary study components: 
1. Documenting the environmental factors that resulted in elevated concentrations of $\mathrm{CO}_{2}$ within the study-site home. This was accomplished by documenting $\mathrm{CO}_{2}$ flux from soils across the study-site landscape; determining the chemistry of spoil samples and masonry materials collected at the study site; establishing an onsite, continuously recording meteorological observation platform; attempting to measure ground-water-level fluctuations within onsite nested monitoring wells; and evaluating $\mathrm{CO}_{2}$ data collected within the study-site home.

2. Documenting the effectiveness of mitigation approaches that could be applied to reduce $\mathrm{CO}_{2}$ levels in homes where $\mathrm{CO}_{2}$ accumulation is a concern. This was accomplished by documenting $\mathrm{CO}_{2}$ levels within the study-site home prior to and in between each successively more complex mitigation approach.

3. Documenting site characteristics for all Indiana homes with known $\mathrm{CO}_{2}$-accumulation issues and using those data to map other locations where this phenomenon could potentially occur. (The methods and results of component 3 are not presented in this report.)

Because carbon dioxide accumulation represents an acute health risk, homeowners try to quickly identify and apply effective mitigation when they first recognize this phenomenon in their home. Therefore, in most cases, there is no opportunity to collect the scientific data required to understand this phenomenon. As mentioned above, for the Pike county studysite home, it was thought that commonly applied mitigation methods would not effectively reduce the within-home $\mathrm{CO}_{2}$ concentrations. Therefore, this home represented the one site where data could be collected to document the $\mathrm{CO}_{2}$-intrusion phenomenon. These data are expected to reveal details regarding $\mathrm{CO}_{2}$ intrusion at the study-site and have a broader application to other structures where this phenomenon may occur.

\section{Purpose and Scope}

An investigation of the phenomenon of $\mathrm{CO}_{2}$ accumulation in a structure constructed on a reclaimed surface coal mine was completed. The purpose of this report is to present data and results for two components of that investigation: the description of the environmental conditions that lead to elevated $\mathrm{CO}_{2}$ concentrations in an east-central Pike County home, and a determination of the effectiveness that three mitigation methods had on reducing indoor $\mathrm{CO}_{2}$ concentrations to acceptable levels.

\section{Methods of Study}

To date, there have been few investigations of the fundamental characteristics and controls for the phenomenon of $\mathrm{CO}_{2}$ accumulation in homes built on top of or near reclaimed coal mines. Therefore, when this investigation was begun, it was recognized that numerous lines of inquiry would be required to fully pursue this subject and that not all lines of inquiry would lead to equal benefit. In this section of the report, methods used to collect geological, meteorological, and gasconcentration data are described. In later sections of the report, the results and significance of these lines of inquiry and the data they produced are discussed.

\section{Geological Data Collection}

One goal of this investigation was to characterize the environmental setting of the study site. Means of addressing this included measurements to document $\mathrm{CO}_{2}$ flux from surface soils; a monitoring-well network to facilitate water-sample collection, documentation of groundwater-flow directions, calculations of vertical and horizontal groundwater gradients, and fluctuations of groundwater levels; and spoil sampling to allow for chemical characterization of the geologic materials of the study site.

\section{Soil-Gas Flux}

To complete a survey of $\mathrm{CO}_{2}$ flux from the study site's soil surface, an evenly spaced grid of sampling cells (fig. 3) was established by using a handheld compass, a mason's line, measuring tapes and wheels, and surveyor's wire flags. The study-site house defined the approximate center of the sampling grid. A mason's line and compass were used to establish straight lines that ran parallel to the outside walls of the studysite house. Surveyor's wire flags and distance-measuring devices where then used to mark the center of each 40 -ft by $40-\mathrm{ft}$ sampling cell. The entire grid of sampling cells consisted of nine base lines, each identified by a letter (A through I). Each base line included nine sampling cells, identified by a number (1 through 9). Although the grid design included 81 sampling cells, physical obstructions on the study-site landscape prevented data collection at eight cells (A1, A2, A3, $\mathrm{B} 1, \mathrm{~B} 2, \mathrm{~B} 3, \mathrm{C} 1$, and F5). This resulted in data being collected at 73 sampling cells. A few cells were visited and measured multiple times to ensure that the results were not biased by instrument drift. 


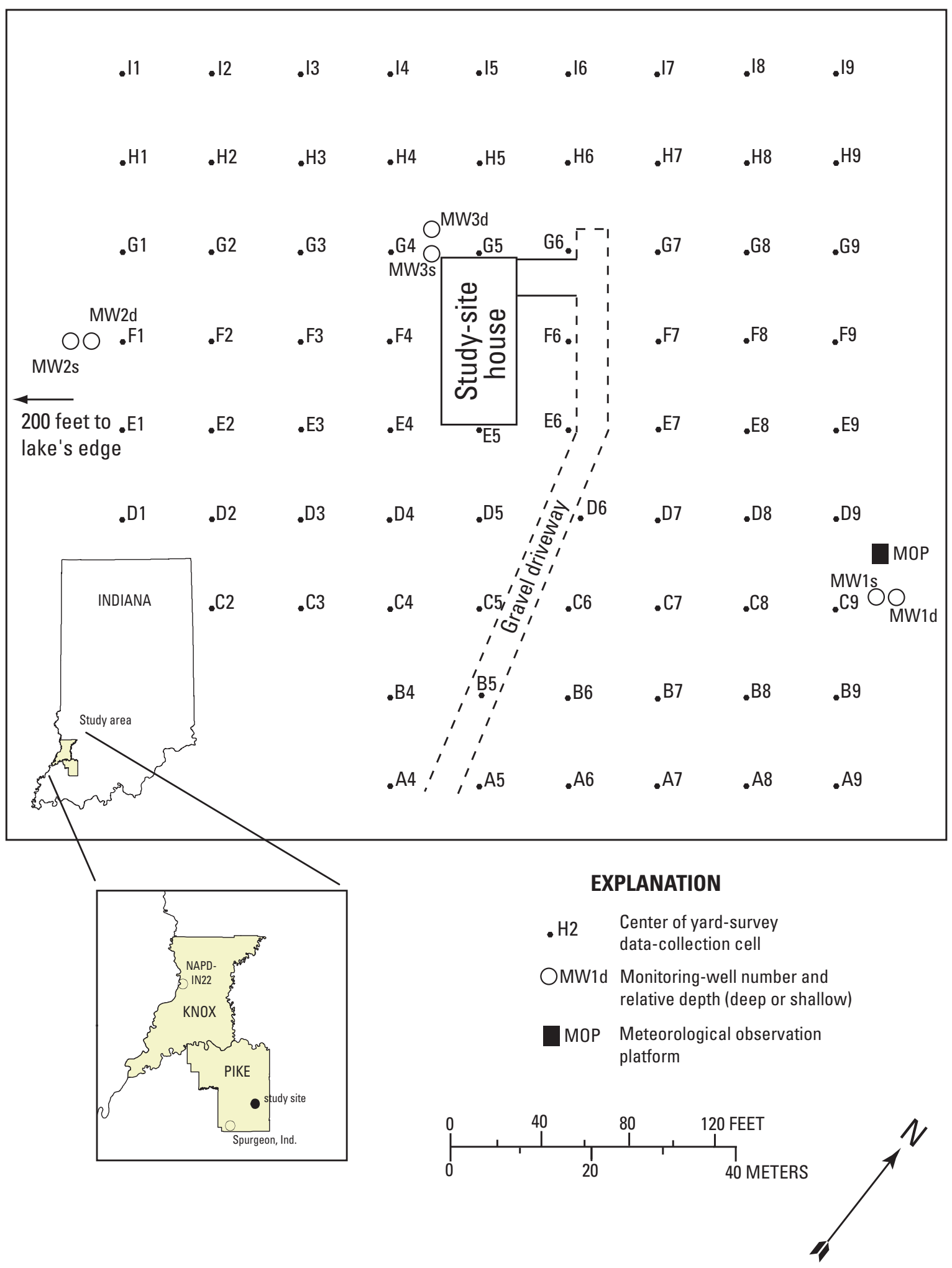

Figure 3. Location of outdoor data-collection sites relative to the study-site house, Pike County, Ind. 
To measure $\mathrm{CO}_{2}$ flux near the center of each sampling cell, a LI-COR LI-8100 portable soil-gas-flux meter (LICOR Environmental, Lincoln, Nebr.) was used. To complete measurements with this device, a sampling collar was seated in the top 2 in. of soil at the locations where soil-gas-flux measurements were to be completed. The LI-8100 gas-collection chamber was then, in turn, placed on each sampling collar, and the device's pneumatic bellows were used to create a seal between those two components of the sampling train. During each data-collection session, the operator could evaluate initial datasets to determine an appropriate duration for instrumentpurging and data-collection times. LI-COR-developed software, designed to support the LI-8100, included a variety of tools to evaluate measurement results and presented $\mathrm{CO}_{2}-$ flux data in units of micromoles per square meter per second $\left(\mu \mathrm{mol} / \mathrm{m}^{2} / \mathrm{s}\right)$.

In addition to measuring $\mathrm{CO}_{2}$ flux for each sampling cell, field personnel also measured and recorded air temperature, barometric pressure, and soil $\mathrm{pH}$. Air temperature was measured with a mercury thermometer, and barometric pressure was measured with a laboratory-grade barometer. Using the method recommended by the manufacturer, soil $\mathrm{pH}$ was measured with a handheld $\mathrm{pH}$ meter. This process involved combining equal weights of soil and de-ionized water (approximately $20 \mathrm{~g}$ ) in a clean beaker, stirring the mixture to form a uniform paste, and then gently stirring with the $\mathrm{pH}$ probe until a stable reading of $\mathrm{pH}$ was obtained.

\section{Well Construction and Groundwater-Level Measurements}

The services of an environmental drilling contractor were used to establish boreholes and install monitoring wells. The temporary network of monitoring wells was designed to allow collection of water samples and measurements of ground-water-level fluctuations at the study site. The network included a total of six 2-in.-diameter wells installed as nested pairs at each of three drilling locations (fig. 3). Each well pair consisted of a deep well, screened from approximately 33 to $38 \mathrm{ft}$ below the land surface, and a shallow well, screened from 13 to $18 \mathrm{ft}$ below the land surface. (The water-well log for the homeowners' water-supply well indicated that bedrock was $38 \mathrm{ft}$ below land surface. This information was used to identify the maximum drilling depth when the drilling contract was established.) Locational data for the monitoring wells is presented in appendix 1 at the back of this report.

The boreholes were drilled with 4.25 -in. inside-diameter hollow-stem augers and a drill rig mounted on an all-terrain vehicle (fig. 4). Each well (table 1) was constructed with a 5-ft-long polyvinylchloride (PVC) well screen and enough PVC well riser to extend the top of the well approximately $2 \mathrm{ft}$ above the land surface. A well-screen sand filter was established in each well and extended approximately $2 \mathrm{ft}$ above the top of the screen. A pump and tremie pipe were used to fill the well annulus with bentonite grout from the top of the sand filter to a level approximately $2 \mathrm{ft}$ below the land surface. At each well, the remaining $2 \mathrm{ft}$ of well annulus was filled with drill cuttings.

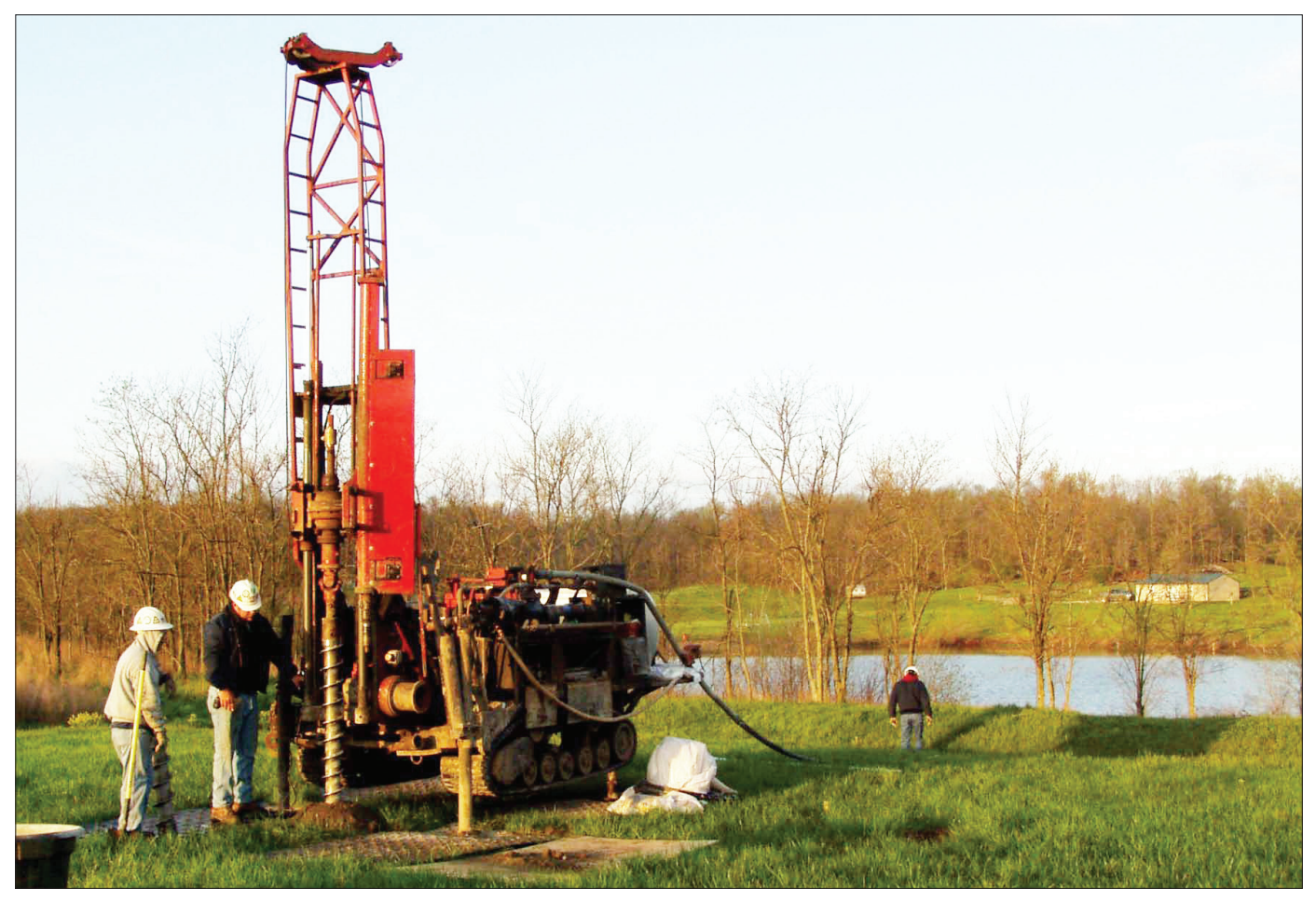

Figure 4. Drilling activities for installation of a temporary network of monitoring wells at the study site in east-central Pike County, Ind. 
Table 1. Selected characteristics of monitoring wells at the study site, Pike County, Indiana.

\begin{tabular}{cccccc}
\hline Well name & Latitude & Longitude & $\begin{array}{c}\text { Screened interval } \\
\text { (feet below land } \\
\text { surface) }\end{array}$ & $\begin{array}{c}\text { Relative } \\
\text { land-surface } \\
\text { elevation' } \\
\text { (feet) }\end{array}$ & $\begin{array}{c}\text { Height of measure- } \\
\text { ment point above land } \\
\text { surface (feet) }\end{array}$ \\
\hline MW1d & $38^{\circ} 19^{\prime} 42^{\prime \prime}$ & $87^{\circ} 08^{\prime} 22^{\prime \prime}$ & $33-38$ & 200.00 & 1.92 \\
MW1s & $38^{\circ} 19^{\prime} 42^{\prime \prime}$ & $87^{\circ} 08^{\prime} 22^{\prime \prime}$ & $13-18$ & 199.62 & 1.52 \\
MW2d & $38^{\circ} 19^{\prime} 40^{\prime \prime}$ & $87^{\circ} 08^{\prime} 27^{\prime \prime}$ & $34-39$ & 188.43 & 0.90 \\
MW2s & $38^{\circ} 19^{\prime} 40^{\prime \prime}$ & $87^{\circ} 08^{\prime} 27^{\prime \prime}$ & $13-18$ & 189.03 & 1.62 \\
MW3d & $38^{\circ} 19^{\prime} 42^{\prime \prime}$ & $8^{\circ} 08^{\prime} 26^{\prime \prime}$ & $33-38$ & 198.36 & 1.27 \\
MW3s & $38^{\circ} 19^{\prime} 42^{\prime \prime}$ & $8^{\circ} 08^{\prime} 26^{\prime \prime}$ & $13-18$ & 199.15 & 1.94 \\
\hline
\end{tabular}

${ }^{1}$ Elevations are referenced to an arbitrary local datum; the measurement point of well MW1d was defined as the arbitrary local datum of 200.00 feet.

The latitude and longitude of each well was established by using a handheld global positioning device (GPS), which referenced the WGS 84 map datum. The relative elevations for each water-level measurement point were established by using conventional surveying techniques, an auto-level, and a stadia rod.

During monthly site visits, an electric measuring tape (commonly referred to as an eTape) was used to document water levels in the monitoring wells. (At the beginning of this investigation, it was thought that these data would allow for determinations of groundwater-flow directions, hydraulic gradients, and groundwater-level fluctuations; however, five of the six monitoring wells were found to be consistently dry, so these calculations could not be completed.)

\section{Spoil Sampling and Chemical Analysis}

During the borehole-drilling process described above, grab samples of the reclaimed coal-mine spoil were collected from various depths below the land surface (appendix 1). The collected samples were briefly described for color and textural characteristics, placed in properly labeled sampling jars, and shipped to the USGS Central Mineral and Environmental Resources Science Center, where they were analyzed for major ions by use of $\mathrm{x}$-ray-diffraction techniques.

\section{Meteorological Data Collection}

Conversations with homeowners who have experienced acute $\mathrm{CO}_{2}$-intrusion events and a review of the relevant literature revealed that certain meteorological conditions may trigger these events. Therefore, meteorological data were collected at the study site to document local meteorological conditions and the $\mathrm{pH}$ of rainwater at the study site.

\section{Meteorological Observation Platform}

At the study site, a meteorological observation platform (figs. 3 and 5) was constructed and relevant data were collected from November 2008 to March 2010. These data included wind direction, wind speed, air temperature, barometric pressure, relative humidity, and precipitation. The first five of the listed parameters were measured by using a Vaisala Weather Transmitter WXT520 (Vaisala Inc., Woburn, Mass.). Precipitation was measured by using a tipping-bucket rain gage. Each data parameter was collected hourly and transmitted via satellite to USGS computers for processing and longterm storage.

\section{Precipitation $\mathrm{pH}$}

A total of five rain samples were collected at the study site, and field measurements were completed to document the $\mathrm{pH}$ of those samples. The samples were collected by placing a clean 12-in.-diameter high-density polyethylene funnel and a collection beaker in the study-site yard during selected rainstorms. After a sufficient volume of water was collected (approximately $150 \mathrm{~mL}$ ), the $\mathrm{pH}$ of the sample was measured with a LaMotte portable $\mathrm{pH}$ meter. This $\mathrm{pH}$ meter was calibrated with standard buffer solutions of $\mathrm{pH} 7$ and $\mathrm{pH} 4$ before each use.

\section{Within-Residence Data Collection}

Because of potential dangers associated with working in a $\mathrm{CO}_{2}$-rich environment, a number of precautions were required during site visits. To ensure the safety of all study personnel, $\mathrm{CO}_{2}$ and $\mathrm{O}_{2}$ levels were monitored continuously when investigation activities required entry to the study-site home. The $\mathrm{CO}_{2}$ monitor has a display window that allows the user to continually monitor $\mathrm{CO}_{2}$ levels and avoid locations where concentrations are above the 5,000-ppm threshold. The $\mathrm{O}_{2}$ monitor projects audible, visual, and tactile alarms when $\mathrm{O}_{2}$ levels fall below 19.5 percent. 


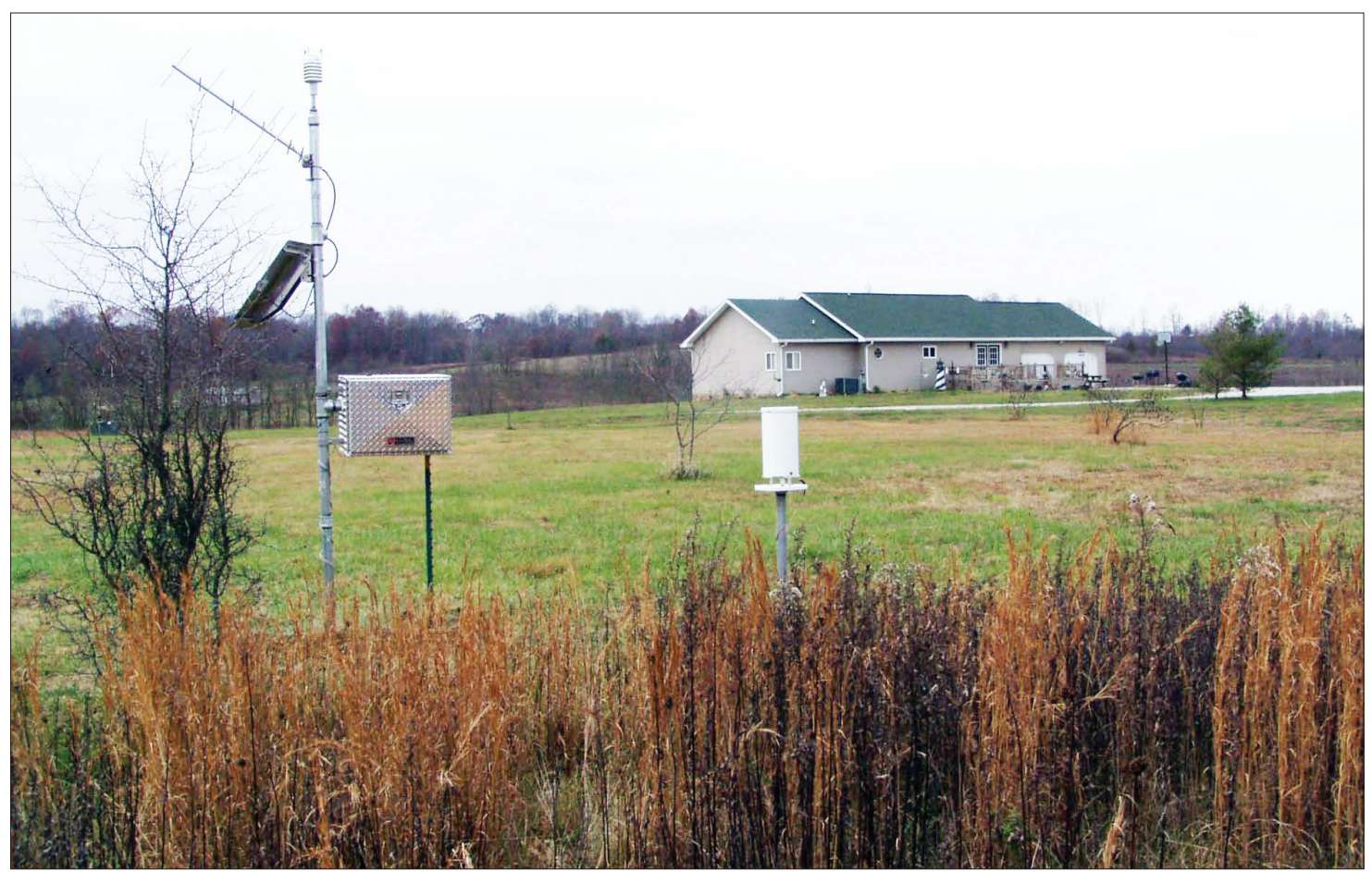

Figure 5. Meteorological observation platform designed for hourly transmission of local meteorological data measured at the Pike County, Ind. study site.

\section{Gas Concentrations}

Personnel from IDNR Division of Reclamation placed and maintained a Draeger X-am 7000 gas monitor (Draeger Safety Inc., Pittsburgh, Pa.) to continuously record $\mathrm{CO}_{2}$ and $\mathrm{O}_{2}$ concentrations at a fixed location in the basement of the studysite home. This device was placed approximately 18 in. above floor level in the room that consistently has shown some of the highest $\mathrm{CO}_{2}$ concentrations when a soil-gas-intrusion event occurs. The instrument was configured to record gas concentrations every 10 minutes. In keeping with the manufacturer's recommendation, the sensors of this device were calibrated every 90 to 120 days or more frequently if the acquired data indicated a need for recalibration (Randy Hoffman, Indiana Department of Natural Resources, Division of Reclamation, oral commun., 2010).

On a biweekly schedule, within-residence gas-concentration data were downloaded from the Draeger unit, and a copy of all downloaded data was provided to the USGS for processing and long-term storage. During processing of these data, all $\mathrm{CO}_{2}$-concentration values collected on a given day (midnight to midnight) were examined to identify the single highest value for that day. Likewise, all $\mathrm{O}_{2}$-concentration values collected on a given day were examined to identify the single lowest value for that day. It is these daily maximum and minimum values of $\mathrm{CO}_{2}$ and $\mathrm{O}_{2}$, respectively, that are archived in the USGS National Water Information System database and referenced in this report.
Several attempts were made to use a Bacharach model 2810 portable $\mathrm{CO}_{2}$ analyzer (Bacharack, Inc., New Kensington, Pa.) to further document $\mathrm{CO}_{2}$ levels in the basement and garage of the study-site home. This analyzer uses infrared absorption to measure $\mathrm{CO}_{2}$ concentrations, was calibrated in fresh air prior to each use, and can be used where $\mathrm{CO}_{2}$ levels range from 0 to $10,000 \mathrm{ppm}$. However, during these attempts it became apparent that even slight disturbances during data collection were profoundly affecting the measured values and prevented this instrument from delivering reproducible results. These disturbances included changes in relative humidity, operator exhalation, movement of people and pets in the home, operation of ceiling fans, status of doors and windows as either open or closed, and furnace or air-conditioner activity.

\section{Masonry Sampling and Chemical Analysis}

Samples were collected from the masonry components of the study-site home and analyzed to determine their chemical composition. In this effort, a total of 10 cores were collected. These cores ranged from 1 to $4 \mathrm{in}$. in diameter and were obtained by masonry-cutting professionals using handheld electric drills and diamond-tipped coring bits. The cores were collected from the garage's concrete slab and the basement's block walls and concrete slab. These sampling locations were selected because they represented points where carbonatebased components of the study-site home were in contact 
with soil. The collected cores were sent to the USGS Central Mineral and Environmental Resources Science Center where they were analyzed for major ions by using $\mathrm{x}$-ray-diffraction techniques. After the cores were obtained, the resultant holes were filled with a concrete-strength, nonshrink epoxy grout to ensure that these holes were well sealed and would not leak gases or moisture to the home's interior.

\section{Occurrence of Within-Residence Carbon Dioxide}

Because the study of the $\mathrm{CO}_{2}$-intrusion phenomenon is in its infancy and many of the underlying controls are not yet well documented, current researchers sometimes explore lines of inquiry that lead to dead ends or need to take a trial and error approach as they employ generally untested methods of data collection. This certainly was the case for the investigation described herein. As part of this investigation, several lines of inquiry were explored that did little to further the understanding of the $\mathrm{CO}_{2}$-intrusion phenomenon. In the interest of brevity, a full description of these lines of inquiry and their resultant data are not presented in this report; rather, the bulleted items below list these study components and briefly describe why they produced results of minimal value.

- At the start of this investigation, the study team expected that groundwater-level fluctuations may be forcing soil gases toward the study-site home during periods of substantial recharge. Therefore, a network of six monitoring wells was established at the study site to create an opportunity to measure groundwater levels. However, in the course of this investigation, five of the six wells were consistently dry, and data collected during this investigation were not able to support or refute the concept that groundwater fluctuations may be physically influencing $\mathrm{CO}_{2}$ intrusion.

- A survey of $\mathrm{CO}_{2}$ flux from the surface soils of the study site was completed to determine whether a few discrete locations - hot spots - were responsible for generating a significant proportion of the $\mathrm{CO}_{2}$ emitted from the study-site landscape. To the contrary, the results of this survey revealed a fairly uniform distribution of $\mathrm{CO}_{2}$ flux from the surface soils of the study site. The measured flux values, which ranged from 1.36 to 6.08 $\mu \mathrm{mol} / \mathrm{m}^{2} / \mathrm{s}$, showed much less variability than values measured by researchers working at other $\mathrm{CO}_{2}$-accumulation sites (Kwame Awuah-Offei, Missouri University of Science and Technology, oral commun., 2010). Therefore, rather than identifying hot spots where corrective measures could be focused, the data showed that $\mathrm{CO}_{2}$ flux was, to a large extent, evenly distributed across the study-site landscape.
- While conducting the $\mathrm{CO}_{2}$-flux survey, the study team also measured soil $\mathrm{pH}$ at each location where $\mathrm{CO}_{2}$-flux values were determined to see whether, as might be expected, there was a strong correlation between soil $\mathrm{pH}$ and $\mathrm{CO}_{2}$ flux rates. However, the resultant data did not reveal a correlation $\left(\mathrm{R}^{2}=0.0013\right)$ and, similar to the uniform distribution of $\mathrm{CO}_{2}$-flux rates, all soil $\mathrm{pH}$ values at the study site fell within a fairly narrow range (4.32 to 6.83) and all were acidic ( $\mathrm{pH}$ values below 7).

- Spoil samples were collected from a variety of depths below the land surface (appendix 1), and their chemical compositions were measured to determine whether the site's geological materials - mostly spoil derived from a shale source- - had a unique chemical composition that could cause them to produce inordinate amounts of $\mathrm{CO}_{2}$ as a soil gas. However, the spoil-chemistry data did not reveal any outstanding characteristics; the median loss-on-ignition value - which can be used to approximate carbonate content - for all spoil samples was 8.5 percent. This value is well within the range of geochemical determinations reported for other shales or shale-derived materials and indicates that unusual spoil chemistry at the study site was not controlling the $\mathrm{CO}_{2}$-intrusion process.

- Likewise, the chemical composition of samples collected from the masonry components of the study-site home were determined to learn whether these materials had a unique chemical quality that would cause them to produce inordinate amounts of $\mathrm{CO}_{2}$ (appendix 1). As with the spoil samples mentioned above, this was not found to be the case.

Although the above-mentioned lines of inquiry did not substantially advance our understanding of the $\mathrm{CO}_{2}$-intrusion phenomenon, they did allow some components of the environmental setting to be excluded from the list of potential determinant factors. A review of all data revealed that coupling of meteorological data and within-residence $\mathrm{CO}_{2}$ data (appendix 1, table 1-5) allowed for identification of the natural factors that most strongly control the occurrence and timing of $\mathrm{CO}_{2}$ intrusion events. (For completeness, the second page of table 1-5 contains the daily minimum $\mathrm{O}_{2}$ values that were measured in the study-site home. Because $\mathrm{CO}_{2}$ tends to displace $\mathrm{O}_{2}$, either of these datasets $\left(\mathrm{CO}_{2}\right.$ or $\left.\mathrm{O}_{2}\right)$ can be used to document the $\mathrm{CO}_{2}$-intrusion phenomenon; however, for consistency within this report, only the $\mathrm{CO}_{2}$ data are discussed.) 


\section{Meteorological Controls}

In most locations rainwater is acidic - has a pH less than 7. This acidity is commonly the result of chemical processes in the lower atmosphere that cause rainwater to combine with available $\mathrm{CO}_{2}$, forming carbonic acid. Data collected by the National Atmospheric Deposition Program (NADP; 2009) show that, for most locations in the United States, rainwater $\mathrm{pH}$ is less than 6, and in the eastern United States, rainwater $\mathrm{pH}$ is typically less than 5. For data collected in 2007 by the NADP at their monitoring location IN22 in Knox County, Ind. (approximately $34 \mathrm{mi}$ from the study site), the annual mean rainwater $\mathrm{pH}$ value was 4.6 (National Atmospheric Deposition Program, 2008).

The NADP results are in close agreement with the measurements of rainwater-pH collected at the study site (table 2). Between December 2008 and March 2010, a total of five samples were collected at the study site for rainwater-pH determinations, and all $\mathrm{pH}$ measurements were 4.6. One component that can promote the generation of $\mathrm{CO}_{2}$ as a soil gas is a source of acidic water in the presence of a carbonate rich substrate. Clearly, with a $\mathrm{pH}$ of 4.6 , this input of acidic water is available at the study site.

For the study-site home, $\mathrm{CO}_{2}$-intrusion events were found to be most closely tied to specific meteorological conditions. These include, but may not be limited to, rapid drops in barometric pressure, rainstorms, and cold weather. These conditions often occur simultaneously and all can, individually or collectively, contribute to the problem of $\mathrm{CO}_{2}$ intrusion to a structure.
Table 2. Determinations of $\mathrm{pH}$ for rainwater samples collected at the study site, Pike County, Ind.

\begin{tabular}{lc}
\hline \multicolumn{1}{c}{ Sampling date } & $\begin{array}{c}\text { Rainwater } \mathbf{~ p H} \\
\text { (standard units) }\end{array}$ \\
\hline December 9, 2008 & 4.6 \\
April 28, 2009 & 4.6 \\
May 14, 2009 & 4.6 \\
March 23, 2010 & 4.6 \\
March 29, 2010 & 4.6 \\
\hline
\end{tabular}

Meteorological and within-residence $\mathrm{CO}_{2}$-concentration data for March 25 to April 25, 2009, are plotted in figure 6. At the top of the figure are vertical bars showing daily maximum $\mathrm{CO}_{2}$ concentrations in the basement of the study-site home. (The "action level" line corresponds to a $\mathrm{CO}_{2}$ concentration of 5,000 ppm, the broadly accepted health standard for $\mathrm{CO}_{2}$.) Barometric-pressure data are presented as a continuous trace through the middle of the figure. Daily precipitation totals are presented as vertical bars at the bottom of the figure. Examination of this plot reveals that, within this 1-month period, substantial and rapid drops in barometric pressure were accompanied by rainfall and spikes in the $\mathrm{CO}_{2}$ concentration on numerous occasions. This general pattern was consistently seen in the study-site home.

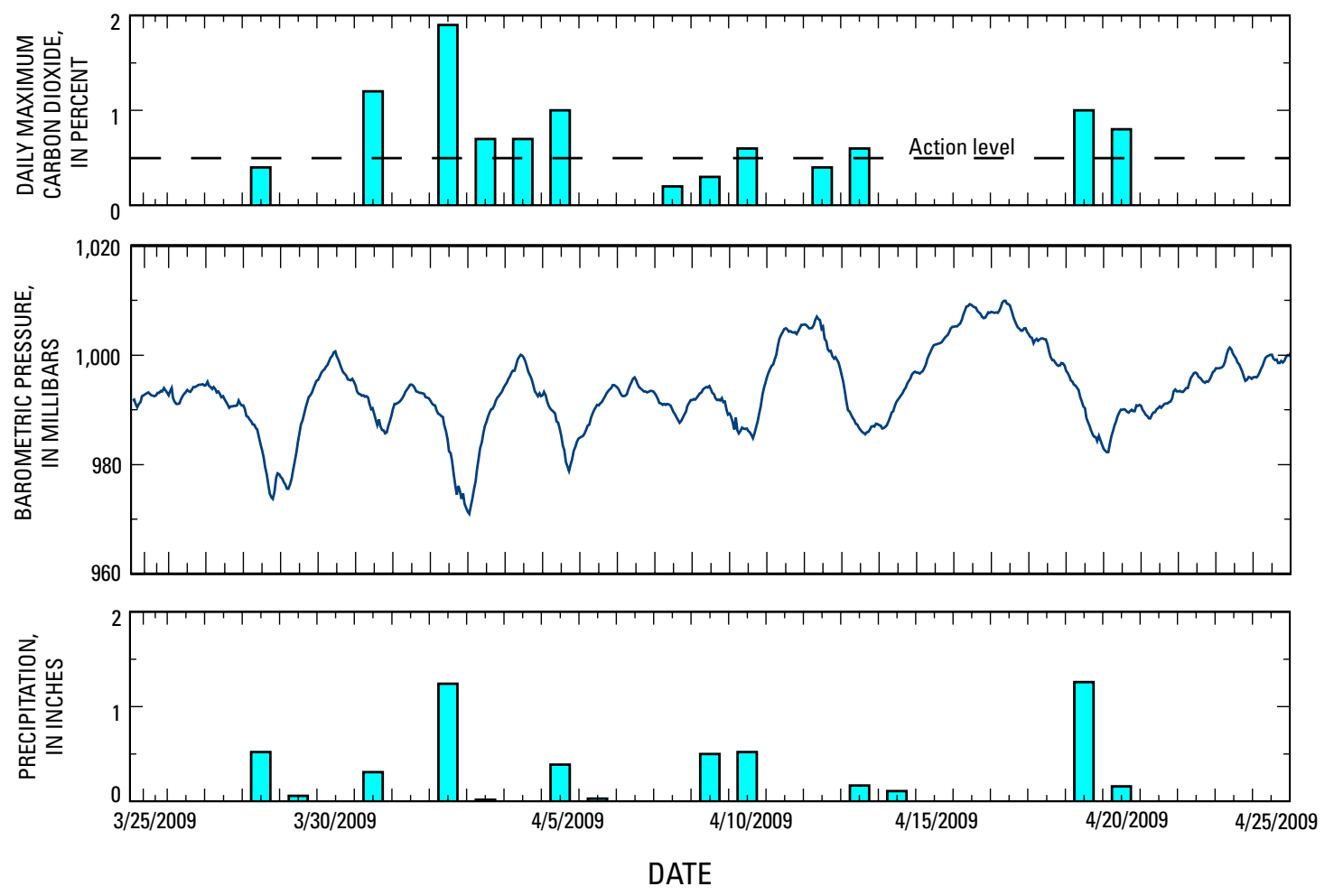

Figure 6. $\mathrm{CO}_{2}$-concentration, barometric-pressure, and precipitation data collected from March 25 to April 25, 2009, at the study site in east-central Pike County, Ind. (Carbon dioxide values that were near background levels and trace amounts of precipitation are not plotted so that meaningful values can be shown at an appropriate scale.) 


\section{Conceptual Model}

Data collected at the study site and a review of the relevant literature led to the development of a conceptual model which, as depicted in figure 7, shows those conditions that drive the $\mathrm{CO}_{2}$-intrusion process. The significance of the controlling components (rapid drops in barometric pressure, rainstorms, windy conditions, and cold weather) shown in this model are briefly described below.

Soil gases naturally move from areas of relative high pressure to areas of relative low pressure. When a weather front causes a rapid drop in barometric pressure to an area, all atmospheric and near-surface gases respond to its effect. The gases inside a structure tend to rise under reduced barometric pressure and, as they rise, soil gases surrounding the structure's foundation are drawn in by the resultant pressure gradient. Soil gases will enter the home via any pathway that allows their transmission: cracks in the house's floor or walls, expansion joints between footers and slabs, locations where plumbing components pass through the outer shell of the structure, and places where porous construction materials allow gas passage.

A syringe in a beaker of water (fig. 8) can be used as a physical model to illustrate this process. When a force is applied to withdraw the plunger from the syringe, a low pressure is generated within the syringe, and water from the beaker is drawn in to fill the potential void. In this physical model, the syringe represents the structure that is influenced by an approaching low-pressure front, and water in the beaker represents the surrounding soil gases that are drawn into the structure as a result of the established pressure gradient.

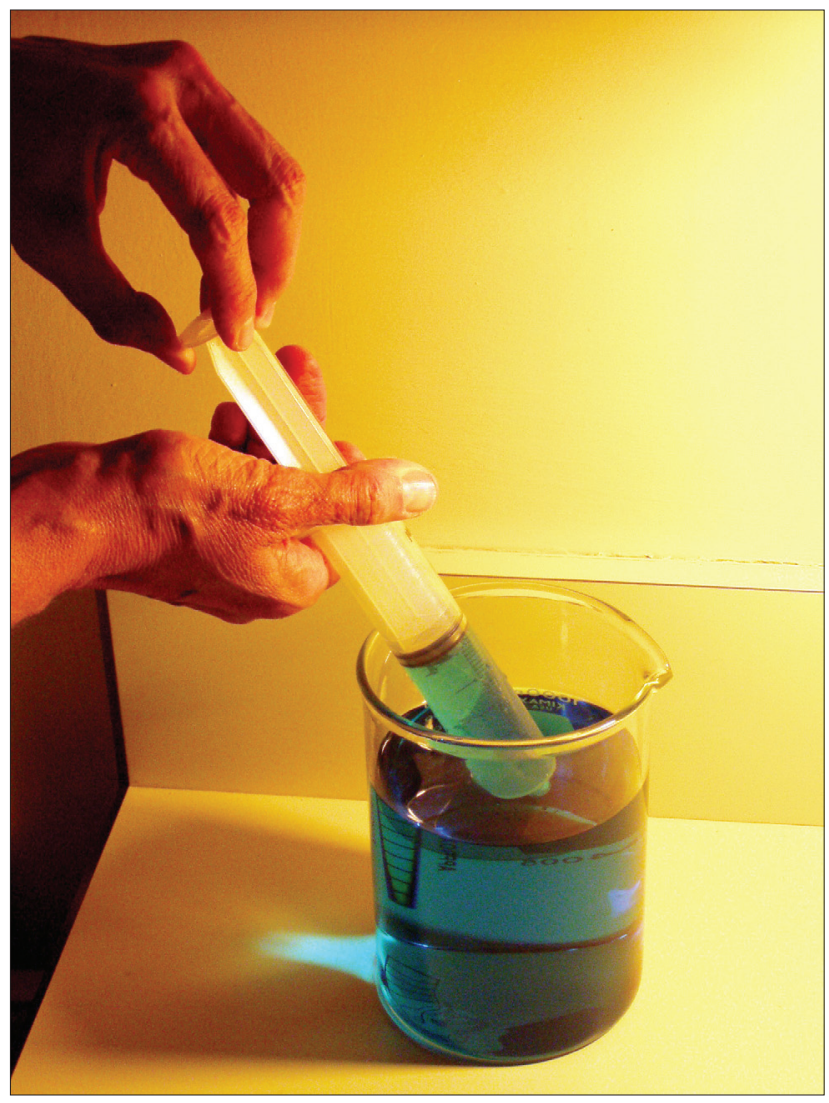

Figure 8. Syringe in a beaker of water, used to illustrate the effect of how a drop in barometric pressure draws soil gases into a structure.

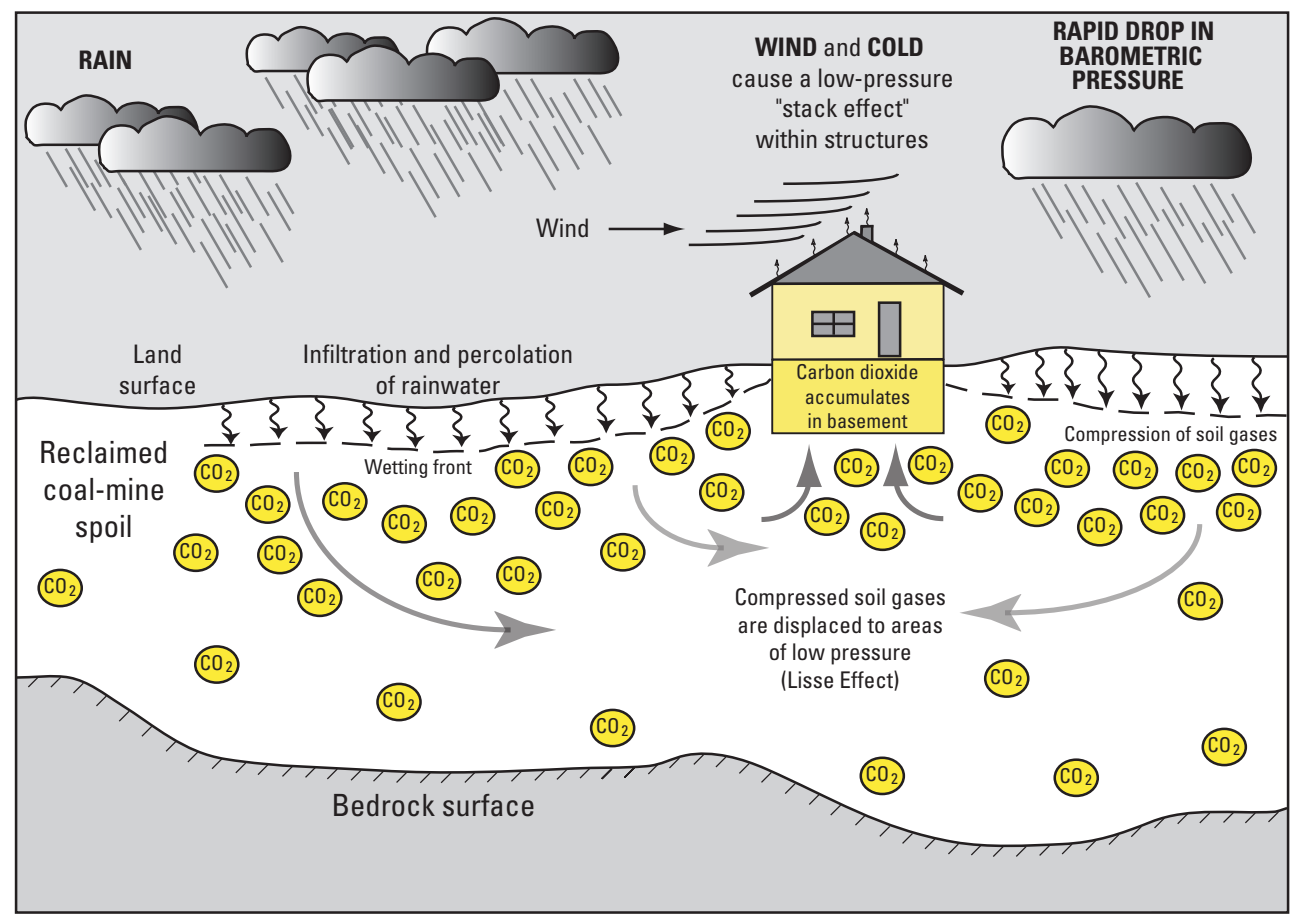

Figure 7. Conceptual model depicting four of the environmental conditions that may lead to carbon dioxide intrusion to structures: rapid drops in barometric pressure, rain, wind, and cold. 
During rainstorms, a phenomenon known as the Lisse effect (Guo and others, 2008) may act to drive soil gases, including $\mathrm{CO}_{2}$, toward a structure or dwelling. With intense rainfall, infiltrating rainwater traps and compresses soil gases which migrate toward areas of low pressure. Because precipitation falling on a house is diverted by manmade drainage systems (the roof, gutters, downspouts, and perimeter drains), the materials directly beneath the footprint of a house do not receive as much infiltrating precipitation as surrounding soils. Therefore, the drier soils beneath a house represent an area of relative low pressure where soil gases tend to migrate and collect (fig. 7).

Soil-gas intrusion is also expected during windy and cold weather (Walker, 2010). During windy conditions a phenomenon, described by the Bernoulli Principle, causes low pressure to form inside a structure as wind blows across the structure's large and small openings. During cold-weather conditions, heating the air inside a structure causes the air to rise and a low-pressure condition to be generated inside the structure (U.S. Environmental Protection Agency, 2010). Therefore, similar to the effect created by an approaching low-pressure front, windy and cold-weather conditions can cause soil gases to be drawn into a structure in response to an established pressure gradient.

In homes where $\mathrm{CO}_{2}$ accumulation is a recognized problem, observations reported by the occupants invariably point to these specific meteorological conditions. The symptoms associated with $\mathrm{CO}_{2}$ intrusion (and oxygen deficiency) are typically most pronounced when atmospheric conditions combine to produce periods of low atmospheric pressure, intense rain, and windy conditions during cold-weather periods. When these conditions are coincident and at their worst, $\mathrm{CO}_{2}$ can be present at concentrations sufficient to cause respiratory problems throughout a structure or home.

\section{Attempted Mitigation}

Often, the least costly approach to addressing a natural hazard is avoidance. In locations where the $\mathrm{CO}_{2}$-intrusion hazard can be anticipated, avoidance may be accomplished by favoring construction on a crawl space and avoiding basements when residential construction is planned. (To date, all $\mathrm{CO}_{2}$-intrusion case studies known to the author consistently link this phenomenon to homes with basements.)

Figure 9. New-construction steps that can be taken to reduce soil-gas intrusion or facilitate mitigation.
Where construction of a basement is planned, several steps can be taken to lessen the problem or facilitate mitigation if soil-gas intrusion is found to occur. These steps are described in a variety of building-guideline publications (Nebraska Department of Health and Human Services, 2007; US Environmental Protection Agency, 2009a, b) and include the following (fig. 9):

- Pouring the basement slab on a layer of aggregate. This aggregate can serve as a soil-gas collection layer if an active mitigation system is to be installed.

- Placing a vapor barrier between the basement slab and the sub-slab aggregate.

- Placing plumbing lines and an electrical junction box at strategic locations to accommodate a future mitigation system if one becomes necessary.

- Sealing all joints, cracks, and surfaces where soil gases may enter the basement.

- Installing gas-proof floor drains and sump-pit covers to inhibit gas intrusion.

Where $\mathrm{CO}_{2}$ intrusion becomes an identified problem, the services of soil-gas-intrusion professionals will be required to design and install a mitigation system. In most locations, these professionals will be identified as offering radon-mitigation services. In the 1970s, an entire industry designed to provide radon mitigation grew around the recognition that radon was a soil gas that could collect in homes and pose a health risk to the inhabitants. Now, as $\mathrm{CO}_{2}$ becomes recognized as another soil gas that poses a potential health risk, radon-mitigation specialists are commonly called for $\mathrm{CO}_{2}$ mitigation.

.

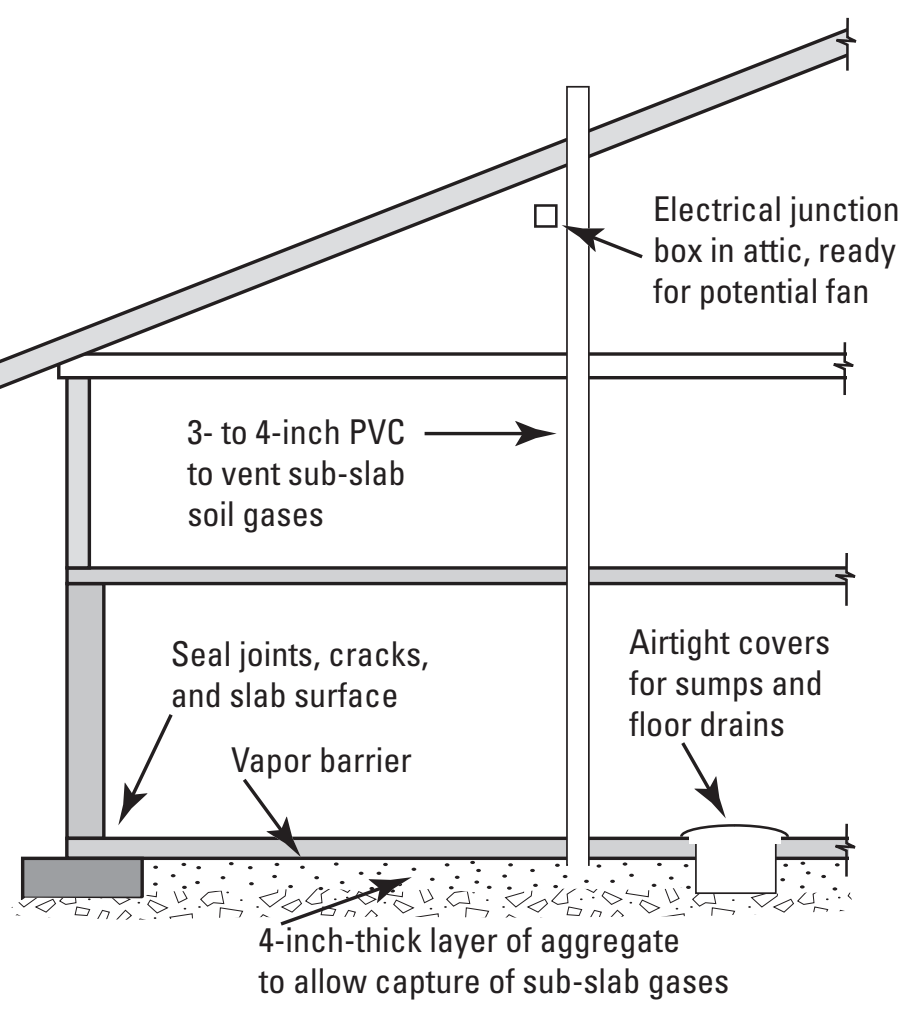


When $\mathrm{CO}_{2}$ intrusion was first recognized as a concern at the study-site home and a radon-mitigation specialist was consulted, it appeared that, for the study-site home, the standard approach for radon mitigation might not resolve the $\mathrm{CO}_{2}$-intrusion concern. The standard approach to radon mitigation is to depressurize the air space beneath a basement's slab (this is the air found between the clasts of a sub-slab aggregate layer) and exhaust the soil gases that collect in the sub-slab space to a safe location above the roofline of the home. At the studysite home, the basement slab was poured without an underlying layer of aggregate and, therefore, without a sub-slab airspace to depressurize.

As part of the investigation described herein, a series of steps were taken to determine whether other soil-gas mitigation approaches could reduce in-home $\mathrm{CO}_{2}$ concentrations to acceptable levels. In this report, three of those mitigation approaches (block-wall depressurization, block-wall and subslab depressurization, and block-wall and sub-slab pressurization) are described and data are presented to evaluate their effectiveness.

\section{Block-Wall Depressurization}

On April 28, 2009, a mitigation system was established to depressurize the block walls of the study-site basement. A small pit was excavated adjacent to the study-site home and an electric drill was used to remove a 4-in.-diameter core from one of the wall blocks. A length of 4-in. PVC pipe was inserted in the cavity of that block and a RadonAway RP 265 fan (RadonAway Inc., Ward Hill, Mass.) was connected to depressurize the basement's block walls (fig. 10) and exhaust the evacuated air to a point just below the home's roofline. The RP 265 fan is a high-volume fan rated to move air at up to 327 cubic feet per minute $\left(\mathrm{ft}^{3} / \mathrm{min}\right)$. To demonstrate that this device was effective at depressurizing the entire perimeter of the basement, a small hole was drilled in the basement wall at the opposite corner of the house and non-thermal smoke was puffed near that hole. The smoke was directly observed being drawn into the drilled hole, thereby confirming that the mitigation system was depressurizing the basement's block walls.

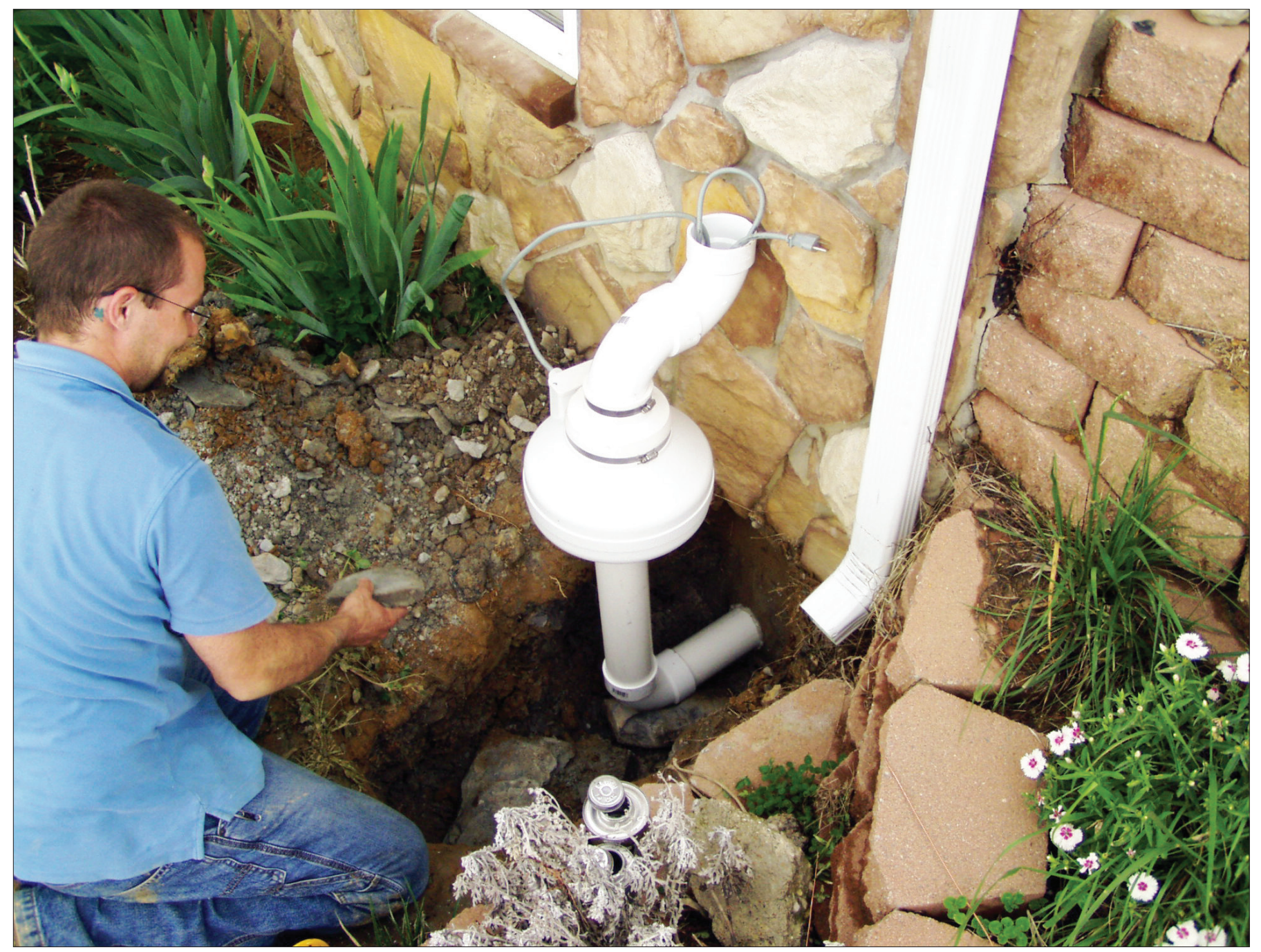

Figure 10. Mitigation system established to depressurize the block walls of the study-site home, Pike County, Ind. 
To determine whether this depressurization effort was sufficient to protect the home from $\mathrm{CO}_{2}$ intrusion, in-home $\mathrm{CO}_{2}$-concentration data were collected for a period of 2 weeks. During this period, the RP265 fan was run continuously. Data collected on May 8, 2009, revealed that a rapid drop in barometric pressure and accompanying rain were still capable of producing a threatening intrusion of $\mathrm{CO}_{2}$ (fig. 11). On this date, $\mathrm{CO}_{2}$ levels in the study-site basement reached a maximum of 0.8 percent, well above the targeted maximum of 0.5 percent. It was therefore concluded that, for the study-site home, block-wall depressurization alone did not provide sufficient protection.

\section{Block-Wall and Sub-Slab Depressurization}

On May 13, 2009, the block-wall depressurization system described above was augmented by a system designed to draw soil gases from beneath the garage and basement slabs of the study-site home. Similar to the block-wall system, subslab depressurization was established by coring through the two slabs and installing a single fan to draw soil gases from beneath both slabs. In this case the fan was a high-pressure
RadonAway GP501, capable of moving $80 \mathrm{ft}^{3} / \mathrm{min}$ of air at a pressure equivalent to 2 in. of water column (WC). This combined system of block-wall and sub-slab depressurization was run continuously for a period of 5 months.

Conditions experienced during the warm-weather period of July to mid-September 2009 did not produce any threatening $\mathrm{CO}_{2}$-intrusion events; however, it was recognized that, for two reasons, this was not the appropriate time of year to evaluate the ultimate effectiveness of any mitigation system. First, during warm months, the furnace in the study-site home does not run, and therefore its potential to create a within-home low-pressure condition- "stack effect"- - and contribute to $\mathrm{CO}_{2}$ intrusion cannot be evaluated. Secondly, because there is little temperature contrast in the summer between southern and northern latitudes of North America, there is little opportunity for strong barometric pressure gradients to form (in meteorological parlance, a barotropic condition). In the spring and fall of most years, when southern and northern temperature contrasts are more pronounced (a condition of baroclinicity) (John Kwiatkowski, National Weather Service, oral commun., 2009), large and rapid pressure drops can occur when midlatitude cyclones develop and move across North America. Therefore,

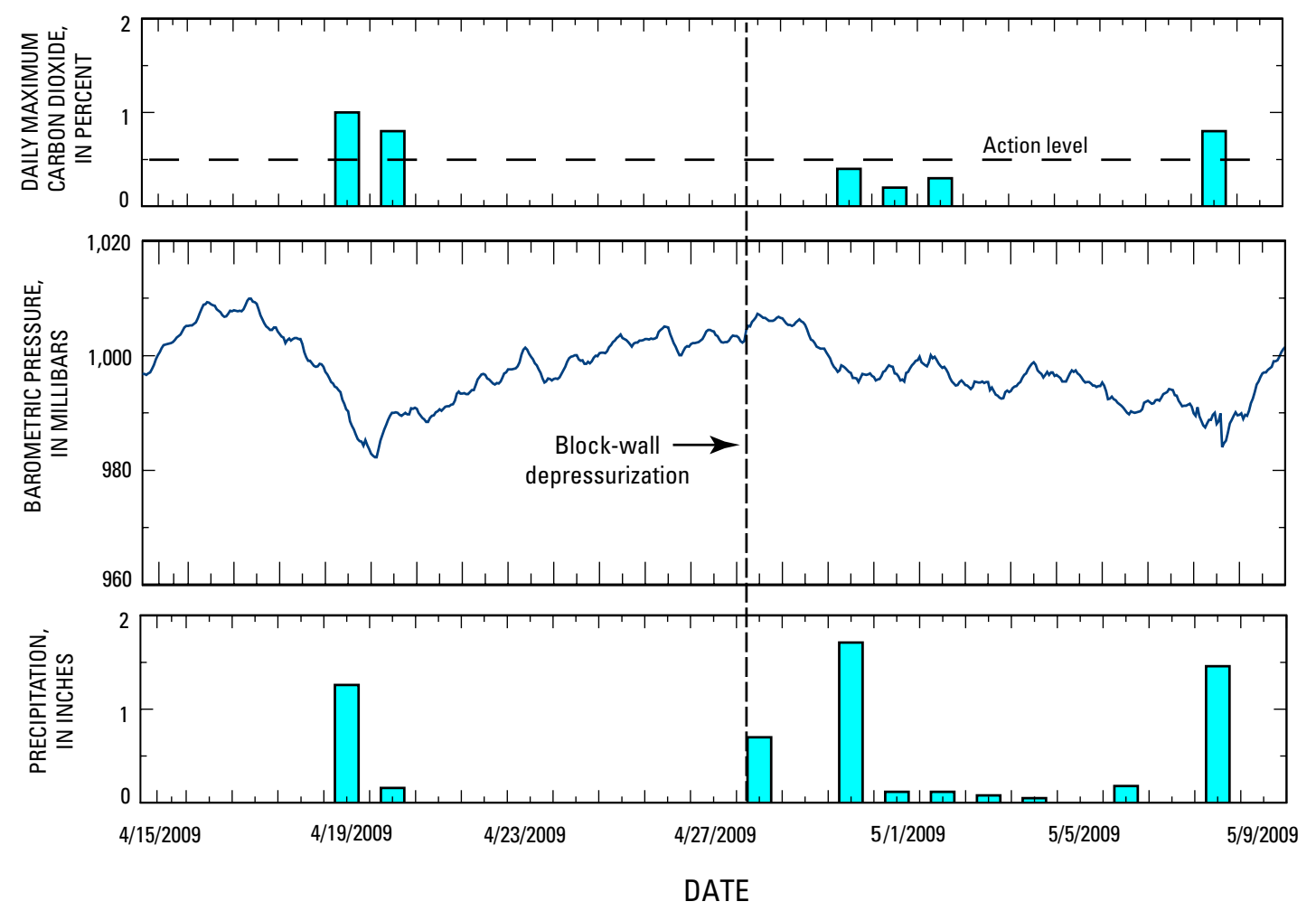

Figure 11. $\quad \mathrm{CO}_{2}$-concentration, barometric-pressure, and precipitation data collected from April 15 to May 10, 2009, at the study site in Pike County, Ind. Block-wall depressurization was established on April 28, 2009. Data collected on May 8, 2009, revealed that this depressurization did not eliminate the $\mathrm{CO}_{2}$-intrusion threat. (Carbon dioxide values that were near background levels and trace amounts of precipitation are not plotted so that meaningful values can be shown at an appropriate scale.) 
because $\mathrm{CO}_{2}$ intrusion is in part triggered by drops in barometric pressure, this phenomenon is more likely to occur in the spring and fall, and mitigation systems are best evaluated then.

To determine whether the combination of block-wall and sub-slab depressurization was producing effective mitigation, in-home $\mathrm{CO}_{2}$-concentration data were plotted with barometric pressure and precipitation data for September 1 to October 13, 2009 (fig. 12). Data collected from September 26 to October 12,2009 , revealed that rapid and substantial drops in barometric pressure were still capable of producing threatening $\mathrm{CO}_{2}$-intrusion events. In this 17-day period, there were 9 days where $\mathrm{CO}_{2}$ concentrations were above the target threshold of 0.5 percent. It was therefore determined that, for the study-site home, the combination of block-wall and sub-slab depressurization did not provide sufficient protection.

\section{Block-Wall and Sub-Slab Pressurization}

On October 21, 2009 the two fans that had been used to draw gases from within the block walls and beneath the slabs of the study-site home were reversed. This reversal of air-flow direction was an attempt to pressurize the block walls and the void spaces immediately below the slabs, thereby preventing soil gases from entering the study-site home.

To determine whether block-wall and sub-slab pressurization was producing the desired mitigation effect, in-home $\mathrm{CO}_{2}$-concentration data were plotted with barometric pressure and precipitation data for October 5 to November 5, 2009 (fig. 13). Data collected between October 22 and 30, 2009, revealed that this pressurization system was not able to prevent $\mathrm{CO}_{2}$ intrusion to the study-site home when atmospheric conditions were conducive to intrusion.
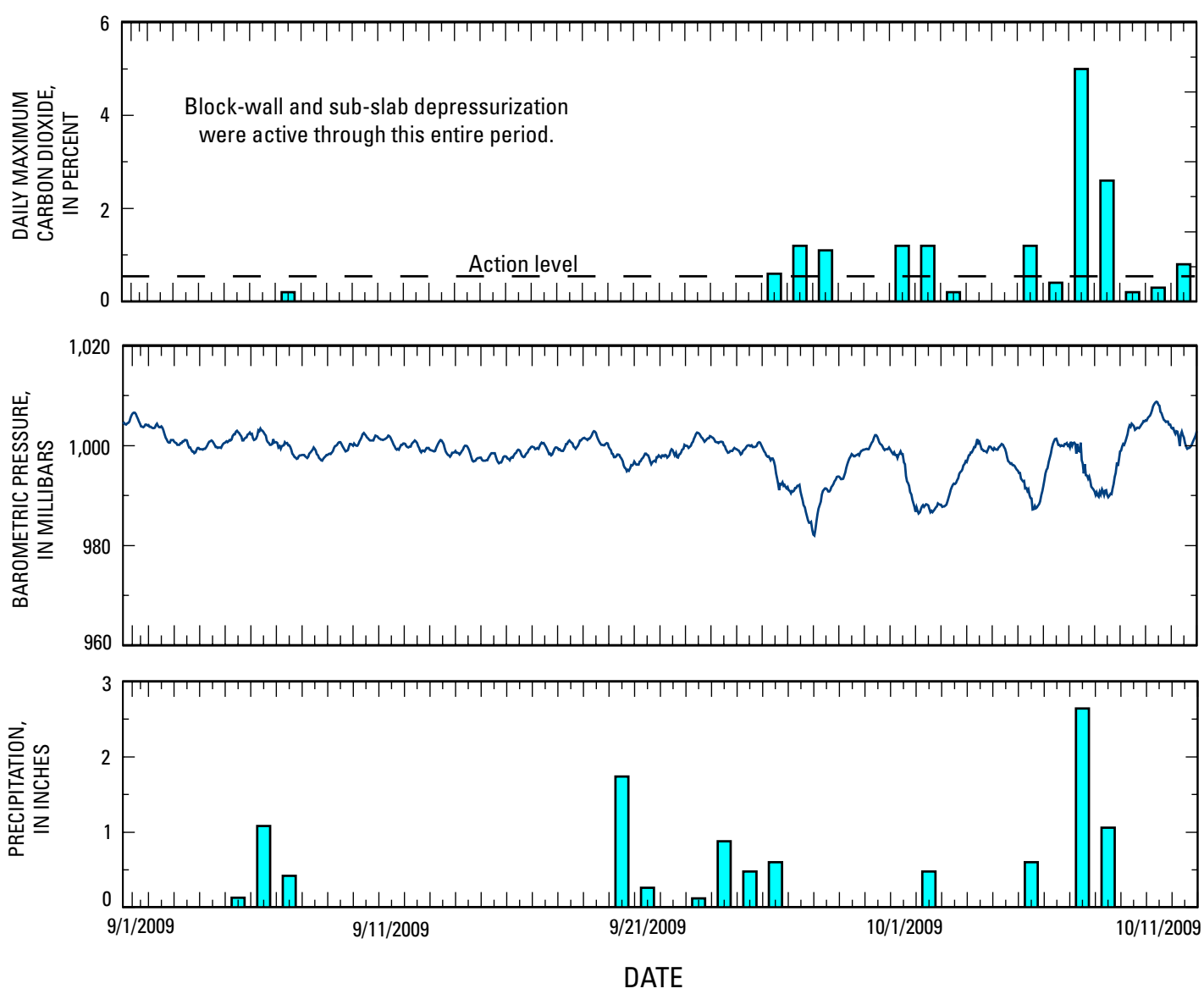

Figure 12. $\mathrm{CO}_{2}$-concentration, barometric-pressure, and precipitation data collected from September 1 to October 13, 2009, at the study site in Pike County, Ind. A combination of block-wall and sub-slab depressurization was established on May 13, 2009. Data collected from September 26 to October 12, 2009, revealed that this expanded depressurization effort did not eliminate the $\mathrm{CO}_{2}$-intrusion threat. (Carbon dioxide values that were near background levels and trace amounts of precipitation are not plotted so that meaningful values can be shown at an appropriate scale.) 


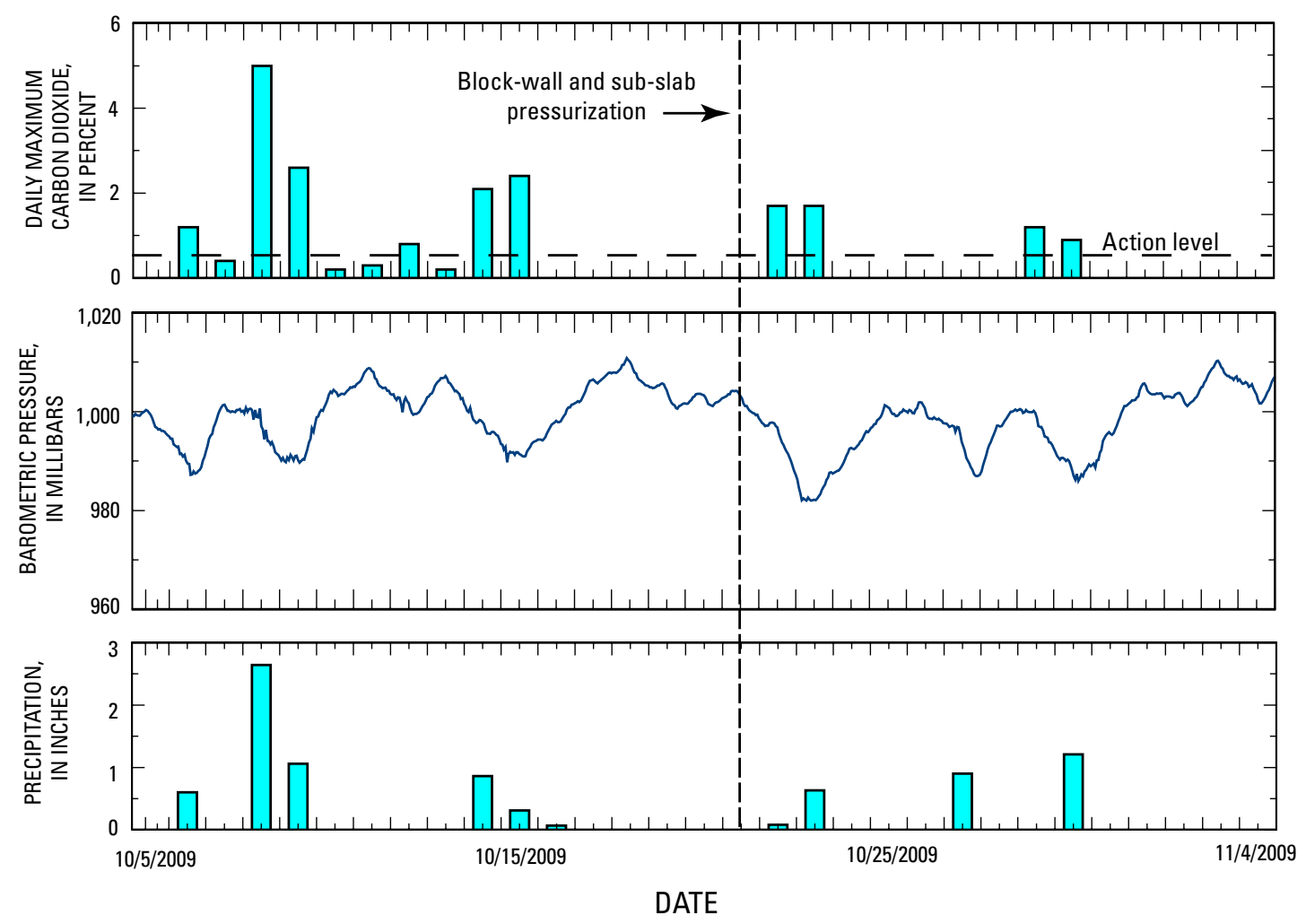

Figure 13. $\mathrm{CO}_{2}$-concentration, barometric-pressure, and precipitation data collected from October 5 to November 5, 2009, at the study site in Pike County, Ind. A combination of block-wall and sub-slab pressurization was established on October 21, 2009. Data collected between October 22 and 30, 2009, revealed that this pressurization effort did not eliminate the $\mathrm{CO}_{2}$-intrusion threat. (Carbon dioxide values that were near background levels and trace amounts of precipitation are not plotted so that meaningful values can be shown at an appropriate scale.)

\section{Limitations Regarding Extrapolation of Mitigation Results}

It should be noted that the results obtained at the Pike County, Ind., study site might not be reproduced if the same mitigation methods were applied at another structure where $\mathrm{CO}_{2}$ intrusion is known to occur. Many site-specific factors, including foundation characteristics, building materials, differential settling of spoil, physical and geochemical properties of the spoil, proximity of the water table, and reclamation methods, can profoundly influence $\mathrm{CO}_{2}$ generation and intrusion. Therefore, though the three mitigation methods described above did not prevent $\mathrm{CO}_{2}$ intrusion at the study site, they might be more beneficial at another site or sites.

\section{Summary and Conclusions}

In recent years, $\mathrm{CO}_{2}$ intrusion has become recognized as a potentially serious health threat where homes are constructed on or near reclaimed coal mines. When $\mathrm{CO}_{2}$ invades the living space of a home, it can collect near the floor, displace the oxygen there, and produce an oxygen-deficient environment. For the individuals living in a home that is experiencing this phenomenon, the severity of the health threat is closely tied to the level of oxygen deficiency. In a slightly oxygen-deficient environment, symptoms may include headaches, dizziness, or confused thinking. In severe cases of oxygen deficiency, individuals can lose consciousness or die.

Several lines of inquiry were pursued to determine the environmental factors that most influenced the $\mathrm{CO}_{2}$-intrusion phenomenon at a study site in Pike County, Ind. From the data collected at the study-site home, $\mathrm{CO}_{2}$-intrusion events were found to be most closely tied to rapid drops in barometric pressure and rainstorms. Results in the relevant literature indicate that wind and cold weather also contribute to the phenomenon of soil-gas intrusion. With this recognition, a conceptual model was developed to illustrate how these four meteorological conditions can individually or collectively contribute to the $\mathrm{CO}_{2}$-intrusion phenomenon.

To evaluate their effectiveness, three mitigation methods were applied to the study-site home: block-wall depressurization, block-wall and sub-slab depressurization, and block-wall and sub-slab pressurization. Block-wall depressurization was accomplished by drilling a 4-in.-diameter hole in one of the 
basement-wall blocks and attaching an exhaust fan designed for radon mitigation. This fan was run continuously for a period of 2 weeks. To establish block-wall and sub-slab depressurization, the system described above was augmented by a fan which drew soil gases from beneath the garage and basement slabs of the study-site home. This combined system of block-wall and sub-slab depressurization was run continuously for a period of 5 months. To establish block-wall and sub-slab pressurization, the air-flow direction of the two fans was reversed, thereby attempting to pressurize the block walls and the void spaces immediately below the slabs and prevent soil gases from entering the study-site home. This pressurization system was run continuously for a period of 1 month.

In each case, it was found that these methods did not ensure a safe environment within the study-site home. Even with these mitigation methods active, $\mathrm{CO}_{2}$ intrusion resulted when meteorological conditions caused a rapid drop in barometric pressure and accompanying rain. It should be noted that, although these mitigation methods did not provide sufficient protection for the study-site home, they might be effective for other structures.

\section{References Cited}

Ehler, W.C., 2002, Dangerous atmosphere created by strip mine spoil: Office of Surface Mining, Federal Reclamation Programs, 16 p., accessed April 4, 2008, at https://fs.ogm. utah.gov/pub/MINES/AMR_Related/NAAMLP/EnDesign/ Ehler.pdf.

Guo, H., Jiao, J.J., and Weeks, E.P., 2008, Rain-induced subsurface airflow and Lisse effect: Water Resources Research, v. 44, no.7, W07409.

Hendrick, D.J., and Sizer, K.E., 1992, "Breathing" coal mines and surface asphyxiation from stythe (black damp): British Medical Journal, v. 305, p. 509-510, accessed January 11, 2010, at http://www.ncbi.nlm.nih.gov/pmc/articles/ PMC1882904/pdf/bmj00089-0033.pdf.

Homer, C., Huang, C., Yang, L., Wylie, B., and Coan, M., 2004, Development of a 2001 National LandCover Database for the United States: Photogrammetric Engineering and Remote Sensing, v. 70, no. 7, p. 829-840.

Indiana Geological Survey, Coal Mine Information System, 2009, accessed October 20, 2009, at http://coalminemaps. indiana.edu/viewer.htm.

Laughrey, C.D., Baldassare, F.J., Ehler, W.C., and Rathburn, S., 2002, Origin of carbon dioxide gas contamination in groundwater and building spaces in western PennsylvaniaImplications for subsurface carbon sequestration [abs.], in 36th Annual Meeting, North-Central Section, Geological Society of America, Lexington, Ky.: Abstracts with Programs 34, p. A-37-A-38.
Midwest Regional Climate Center, 2009, Historical climate data, accessed May 3, 2010, at http://mcc.sws.uiuc.edu/ prod_serv/prodserv.htm.

National Atmospheric Deposition Program, 2008, National Atmospheric Deposition Program/National trends network 2007 annual and seasonal data summary for site IN22, accessed January 13, 2010, at http://nadp.sws.uiuc.edu/ ads/2007/IN22.pdf.

National Atmospheric Deposition Program, 2009, 2008 isopleth maps, accessed January 13, 2010, at https://nadp.isws. illinois.edu/isopleths/maps2008/phlab.pdf.

National Institute for Occupational Safety and Health, 2004, NIOSH respirator selection logic 2004, accessed January 11, 2010, at $h t t p: / / w w w . c d c . g o v / n i o s h / d o c s / 2005-100 /$ chapter5.html.

Nebraska Department of Health and Human Services, 2007, Radon resistant new construction: 2 p., accessed August 12, 2009, at http://www.hhs.state.ne.us/radon/docs/RRNC.pdf.

Occupational Safety \& Health Administration, 2009, Table Z-1, limits for air contaminants, accessed January 21, 2009, at http://www.osha.gov/pls/oshaweb/owadisp.show_ document? $p \_$table $=S T A N D A R D S \& p \_i d=9992$.

Rao, K., and Kreiss, C.Y., 2004, Investigation of a home with extremely elevated carbon dioxide levels - West Virginia, December 2003: Morbidity and Mortality Weekly Report, December 24, 2004, accessed April 4, 2008, at http:// findarticles.com/p/articles/mi_m0906/is_50_53/ai_n8965045/ print.

U.S. Environmental Protection Agency, 2009a, Basic techniques for radon-resistant new construction, accessed January 13,2010 , at $h t t p: / / w w w . e p a . g o v / r a d o n / r r n c / b a s i c \_t e c h-$ niques_builder.html.

U.S. Environmental Protection Agency, 2009b, Home buyer's and seller's guide to radon: EPA 402/K-09/002, 38 p., accessed January 13, 2010, at http://www.epa.gov/radon/ pubs/hmbyguid.html.

U.S. Environmental Protection Agency, 2010, Indoor air quality—Glossary of terms, accessed May 4, 2010, at http:// www.epa.gov/iaq/glossary.html.

Walker, Andy, 2010, Natural ventilation: National Institute of Building Sciences, Whole Building Design Guide, accessed May 3, 2010, at http://www.wbdg.org/resources/naturalventilation.php. 
Appendix 1. Detailed Descriptive and Analytical Data From the Study Site.

Table 1-1. Locational data for spoil samples collected at the carbon dioxide-accumulation study site in Pike County, Ind.

\begin{tabular}{cccc}
\hline $\begin{array}{c}\text { Sample } \\
\text { identification }\end{array}$ & Latitude & Longitude & $\begin{array}{c}\text { Sampling } \\
\text { depth (feet } \\
\text { below land } \\
\text { surface) }\end{array}$ \\
\hline MW1d-1 & $38^{\circ} 19^{\prime} 42^{\prime \prime}$ & $87^{\circ} 08^{\prime} 22^{\prime \prime}$ & 2 \\
MW1d-2 & $38^{\circ} 19^{\prime} 42^{\prime \prime}$ & $87^{\circ} 08^{\prime} 22^{\prime \prime}$ & 7 \\
MW1d-3 & $38^{\circ} 19^{\prime} 42^{\prime \prime}$ & $87^{\circ} 08^{\prime} 22^{\prime \prime}$ & 13 \\
MW1d-4 & $38^{\circ} 19^{\prime} 42^{\prime \prime}$ & $87^{\circ} 08^{\prime} 22^{\prime \prime}$ & 23 \\
MW1d-5 & $38^{\circ} 19^{\prime} 42^{\prime \prime}$ & $8^{\circ} 08^{\prime} 22^{\prime \prime}$ & 38 \\
MW1d-6 & $38^{\circ} 19^{\prime} 42^{\prime \prime}$ & $8^{\circ} 08^{\prime} 22^{\prime \prime}$ & 38.5 \\
MW2d-1 & $38^{\circ} 19^{\prime} 40^{\prime \prime}$ & $87^{\circ} 08^{\prime} 27^{\prime \prime}$ & 3 \\
MW2d-2 & $38^{\circ} 19^{\prime} 40^{\prime \prime}$ & $8^{\circ} 08^{\prime} 27^{\prime \prime}$ & 8 \\
MW2d-3 & $38^{\circ} 19^{\prime} 40^{\prime \prime}$ & $87^{\circ} 08^{\prime} 27^{\prime \prime}$ & 18 \\
MW2d-4 & $38^{\circ} 19^{\prime} 40^{\prime \prime}$ & $87^{\circ} 08^{\prime} 27^{\prime \prime}$ & 29 \\
MW2d-5 & $38^{\circ} 19^{\prime} 40^{\prime \prime}$ & $87^{\circ} 08^{\prime} 27^{\prime \prime}$ & 39 \\
MW3d-1 & $38^{\circ} 19^{\prime} 42^{\prime \prime}$ & $87^{\circ} 08^{\prime} 26^{\prime \prime}$ & 3 \\
MW3d-2 & $38^{\circ} 19^{\prime} 42^{\prime \prime}$ & $87^{\circ} 08^{\prime} 26^{\prime \prime}$ & 8 \\
MW3d-3 & $38^{\circ} 19^{\prime} 42^{\prime \prime}$ & $87^{\circ} 08^{\prime} 26^{\prime \prime}$ & 18 \\
MW3d-4 & $38^{\circ} 19^{\prime} 42^{\prime \prime}$ & $8^{\circ} 08^{\prime} 26^{\prime \prime}$ & 23 \\
MW3d-5 & $38^{\circ} 19^{\prime} 42^{\prime \prime}$ & $8^{\circ} 08^{\prime} 26^{\prime \prime}$ & 28 \\
MW3d-6 & $38^{\circ} 19^{\prime} 42^{\prime \prime}$ & $87^{\circ} 08^{\prime} 26^{\prime \prime}$ & 38 \\
\hline
\end{tabular}

Table 1-2. Results of major-ion analysis of spoil samples collected at the study site in Pike County, Ind.

[All data are expressed as percent of sample, by weight]

\begin{tabular}{|c|c|c|c|c|c|c|c|c|c|c|c|c|}
\hline $\begin{array}{c}\text { Sample } \\
\text { identifica- } \\
\text { tion }\end{array}$ & $\mathrm{Al}_{2} \mathrm{O}_{3}$ & $\mathrm{CaO}$ & $\mathrm{Cr}_{2} \mathrm{O}_{3}$ & $\mathrm{Fe}_{2} \mathrm{O}_{3}$ & $\mathrm{~K}_{2} \mathrm{O}$ & $\mathrm{MgO}$ & MnO & $\mathrm{Na}_{2} \mathrm{O}$ & $\mathbf{P}_{2} \mathbf{O}_{5}$ & $\mathrm{SiO}_{2}$ & $\mathrm{TiO}_{2}$ & $\begin{array}{l}\text { Loss on } \\
\text { ignition }\end{array}$ \\
\hline MW1d-1 & 13.6 & 0.46 & 0.01 & 6.61 & 2.16 & 1.05 & 0.11 & 0.67 & 0.20 & 66.5 & 0.94 & 7.48 \\
\hline MW1d-2 & 16.1 & 0.40 & $<0.01$ & 6.09 & 2.78 & 1.83 & 0.08 & 1.03 & 0.13 & 62.8 & 1.03 & 6.98 \\
\hline MW1d-3 & 16.8 & 0.68 & $<0.01$ & 6.19 & 2.92 & 1.76 & 0.10 & 0.96 & 0.15 & 61.8 & 0.94 & 7.83 \\
\hline MW1d-4 & 15.8 & 0.83 & 0.01 & 6.36 & 2.73 & 1.66 & 0.09 & 0.96 & 0.19 & 61.2 & 0.93 & 8.77 \\
\hline MW1d-5 & 16.2 & 0.58 & $<0.01$ & 6.58 & 2.72 & 1.75 & 0.10 & 0.99 & 0.18 & 60.3 & 1.00 & 8.67 \\
\hline MW1d-6 & 15.3 & 0.61 & 0.02 & 6.19 & 2.53 & 1.52 & 0.09 & 0.87 & 0.19 & 62.6 & 0.95 & 8.12 \\
\hline MW2d-1 & 16.4 & 0.66 & 0.01 & 6.41 & 2.85 & 1.64 & 0.10 & 0.90 & 0.15 & 60.7 & 0.93 & 8.72 \\
\hline MW2d-2 & 14.6 & 1.31 & 0.01 & 5.11 & 2.45 & 1.56 & 0.09 & 1.11 & 0.15 & 66.3 & 0.94 & 6.66 \\
\hline MW2d-3 & 17.2 & 0.53 & 0.01 & 6.64 & 2.99 & 1.66 & 0.11 & 0.86 & 0.16 & 60.0 & 0.94 & 8.46 \\
\hline MW2d-4 & 14.0 & 1.14 & 0.01 & 5.18 & 2.16 & 1.44 & 0.07 & 0.83 & 0.22 & 64.9 & 0.91 & 8.30 \\
\hline MW2d-5 & 14.0 & 0.81 & 0.01 & 6.37 & 2.28 & 1.52 & 0.09 & 0.94 & 0.14 & 65.4 & 0.94 & 7.31 \\
\hline MW3d-1 & 12.9 & 0.24 & 0.01 & 5.78 & 2.20 & 0.84 & 0.06 & 0.76 & 0.12 & 69.1 & 0.82 & 7.40 \\
\hline MW3d-2 & 19.5 & 0.66 & 0.02 & 5.13 & 2.10 & 1.22 & 0.06 & 0.59 & 0.20 & 54.9 & 0.94 & 14.80 \\
\hline MW3d-3 & 17.5 & 0.52 & $<0.01$ & 7.27 & 3.04 & 1.93 & 0.12 & 0.95 & 0.17 & 57.6 & 0.95 & 10.40 \\
\hline MW3d-4 & 16.1 & 0.76 & 0.02 & 6.80 & 2.80 & 1.87 & 0.11 & 0.99 & 0.31 & 57.8 & 0.95 & 11.40 \\
\hline MW3d-5 & 16.7 & 0.55 & $<0.01$ & 7.10 & 2.84 & 1.87 & 0.12 & 1.03 & 0.18 & 59.8 & 1.02 & 8.93 \\
\hline MW3d-6 & 16.2 & 1.22 & 0.01 & 7.23 & 2.83 & 1.67 & 0.11 & 0.79 & 0.27 & 57.2 & 0.86 & 10.70 \\
\hline
\end{tabular}


Table 1-3. Description of materials and locations where masonry samples were collected from the study-site home in Pike County, Ind.

\begin{tabular}{cll}
\hline Sample identification & Material sampled & Location of sample collection \\
\hline HRM1 & Concrete & Garage floor \\
HRM2 & Concrete & Garage floor \\
HRM3 & Block & Basement wall (near ceiling) \\
HRM4 & Block & Basement wall (near floor) \\
HRM5 & Concrete & Basement floor \\
HRM6 & Concrete & Basement floor \\
HRM6D & Concrete & Basement floor (split duplicate) \\
HRM7 & Concrete & Basement floor \\
HRM7D & Concrete & Basement floor (split duplicate) \\
HRM8 & Concrete & Basement floor \\
HRM9 & Block & Garage foundation (inside) \\
HRM10 & Block & Basement wall (outside) \\
\hline
\end{tabular}

Table 1-4. Results of major-ion analysis of masonry samples collected from the study-site home in Pike County, Ind.

[All data are expressed as percent of sample, by weight]

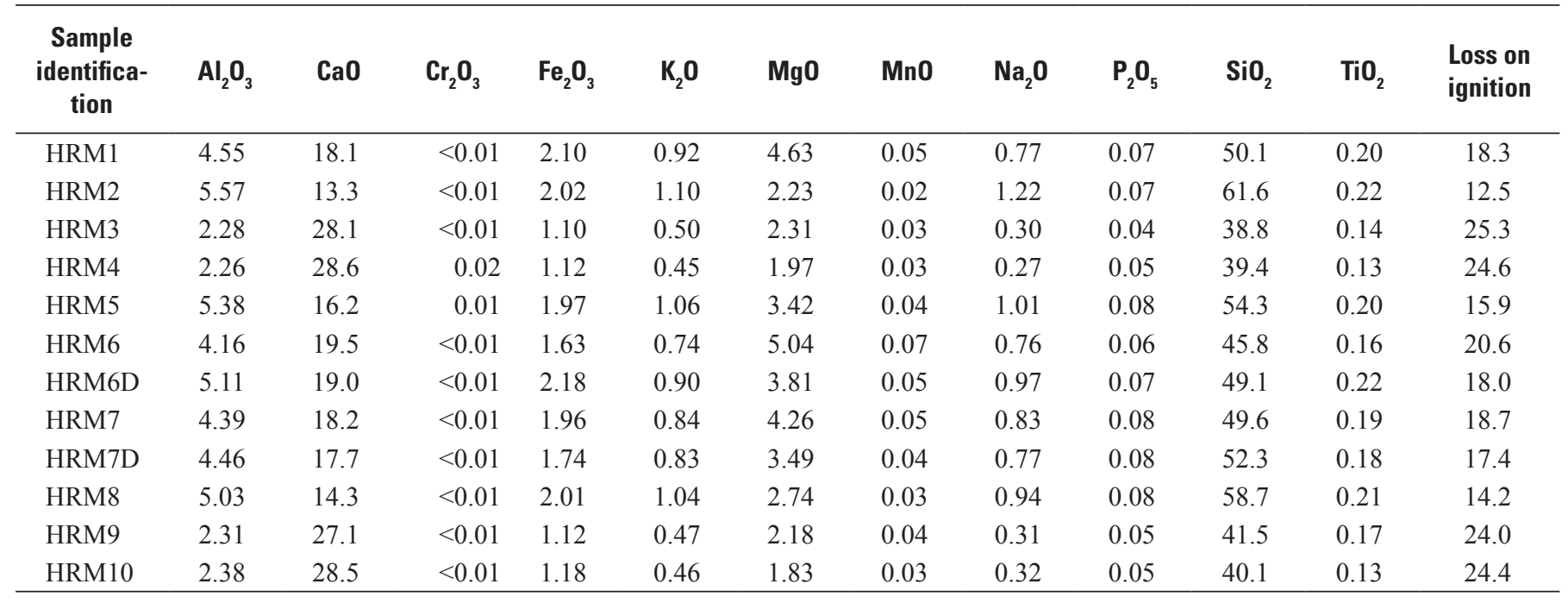




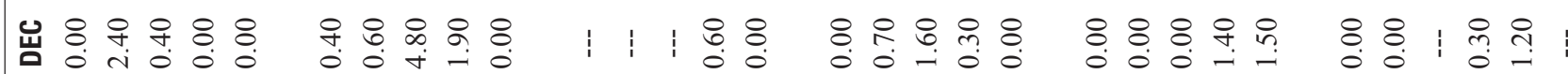

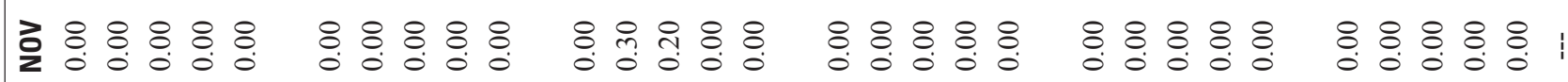

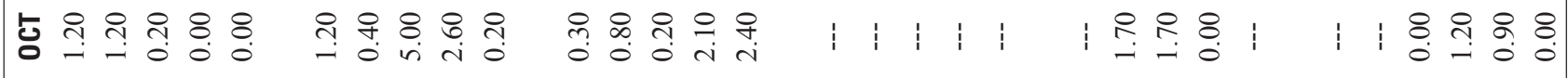

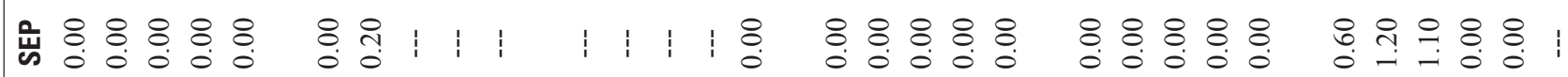

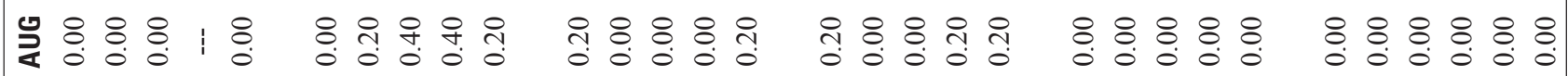

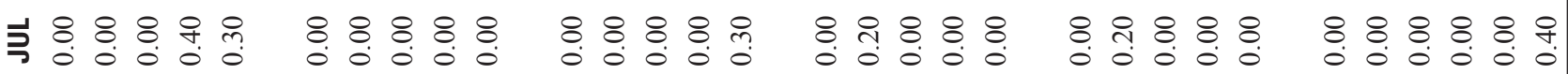

긱

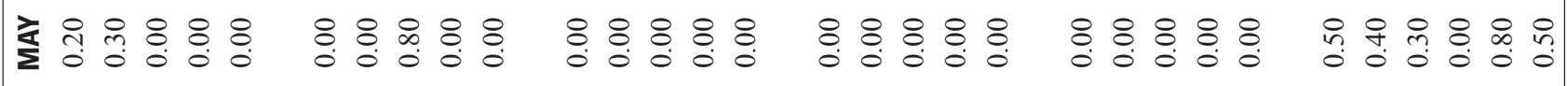

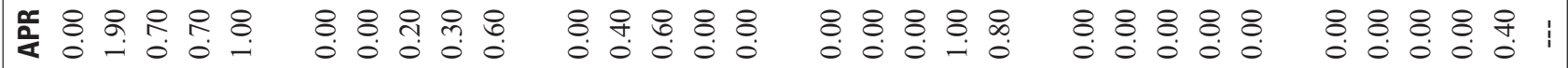

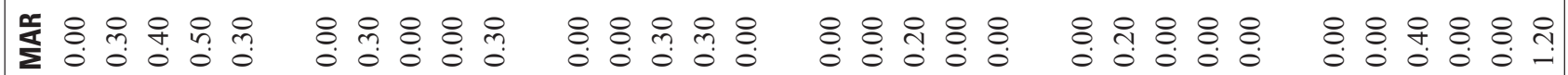

出

3
5

竞-4m+n 


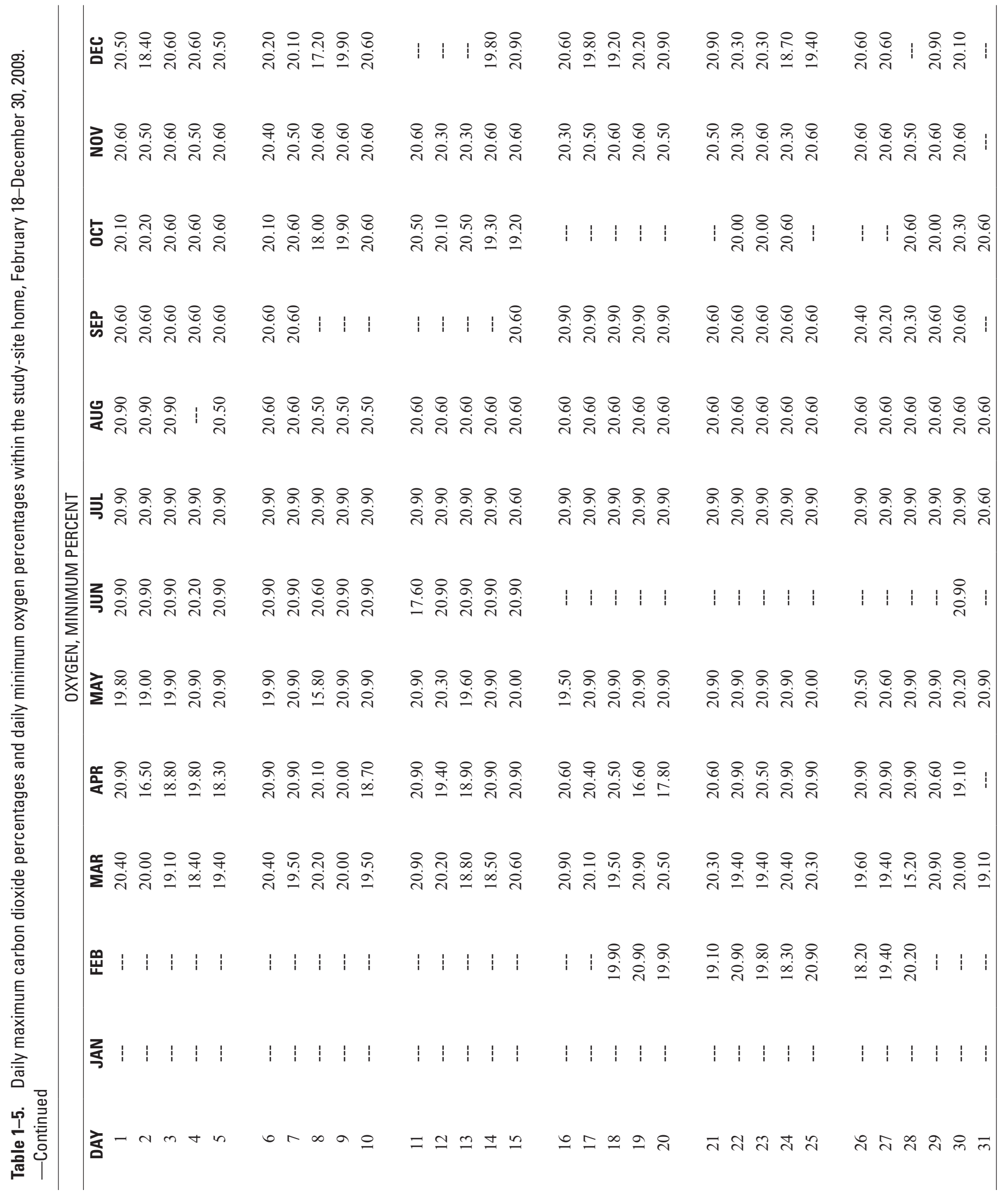


